\title{
Challenges Perceived by Cooperating Teachers when Supervising Student Teachers in Agricultural Education
}

\author{
Samantha L. Cogle
}

Follow this and additional works at: https://researchrepository.wvu.edu/etd

\section{Recommended Citation}

Cogle, Samantha L., "Challenges Perceived by Cooperating Teachers when Supervising Student Teachers in Agricultural Education" (2017). Graduate Theses, Dissertations, and Problem Reports. 5379. https://researchrepository.wvu.edu/etd/5379

This Thesis is protected by copyright and/or related rights. It has been brought to you by the The Research Repository @ WVU with permission from the rights-holder(s). You are free to use this Thesis in any way that is permitted by the copyright and related rights legislation that applies to your use. For other uses you must obtain permission from the rights-holder(s) directly, unless additional rights are indicated by a Creative Commons license in the record and/ or on the work itself. This Thesis has been accepted for inclusion in WVU Graduate Theses, Dissertations, and Problem Reports collection by an authorized administrator of The Research Repository @ WVU. For more information, please contact researchrepository@mail.wvu.edu. 
Challenges Perceived by Cooperating Teachers when Supervising Student Teachers in Agricultural Education

\author{
Samantha L. Cogle
}

Thesis Submitted to the

Davis College of Agriculture, Natural Resources and Design

at West Virginia University

in partial fulfillment of the requirements

for the degree of

Master of Science

in

Agricultural and Extension Education

\author{
Stacy A. Gartin, Ph.D., Chair \\ Harry N. Boone Jr., Ph.D. \\ Jessica M. Blythe, Ph.D.
}

School of Design and Community Development

Morgantown, WV

2017

Keywords: Agricultural Education, Agriculture, Education,

Cooperating Teachers, Student Teachers 


\begin{abstract}
Challenges Perceived by Cooperating Teachers when Supervising Student Teachers in Agricultural Education
\end{abstract}

\title{
Samantha L. Cogle
}

Cooperating teachers face challenges when supervising student teachers. This study aimed to identify perceived challenges by secondary agricultural educators when supervising a student teacher from West Virginia University’s Agricultural Education and Extension department. The cooperating teachers were asked to identify perceived challenges that their student teachers encountered along with the challenges they encountered as a cooperating teacher. The study also aimed to discover how significant the cooperating teachers felt those challenges were and how frequently they occurred with student teachers they had. Using a descriptive research modified Delphi study the population was able to list the challenges and express the significance and frequency of those challenges. The results from all three phases produced different challenges that cooperating teachers perceived. Phase II produced 14 challenges related to the student teacher and three challenges rated to the cooperating teacher. These included discipline procedures, content knowledge, preparation, time management, and time commitment to the student teaching experience. The three challenges cooperating teachers identified themselves encountering were related to needed materials and time commitment associated with being a student teacher in the agricultural education field. Based on the results of the study department faculty is able to address them before sending student teachers out. The study also opened other windows for research. 


\section{ACKNOWLEDGEMENTS}

I would like to take this time to thank everyone who played a role in the completion of this study. To my committee members, Dr. Gartin, Dr. Boone, and Dr. Blythe, thank you very much for all time and effort you have put into helping me complete my research. Dr. Gartin, thank you for serving as the chair of my committee and my graduate advisor, I have thoroughly enjoyed working with you the past four years during my undergraduate and graduate work. I could never thank you enough for all the opportunities, support, advice, and encouragement you have given me over the years, it is truly appreciated. Dr. Boone, thank you for your expert knowledge in data analysis and for starting me off on the right foot in my research, I am very thankful for all you have done. Dr. Blythe, thank you for always being there to answer my many questions, I am grateful for all you help and support.

To my parents, siblings, and family, thank you for always believing in me and constantly giving me words of encouragement. Mom and Dad, you have taught me not to give up even when things get tough or I have hit a roadblock. I am forever grateful for your love and support throughout this process. Cole, thank you for your support, constant motivation for me to always do my best, and reminding me everything would work out, even when I was stressed and overwhelmed.

To all of the cooperating teachers, thank you for your responses and for your supervision of student teachers. It is because of you, others as well as myself are able to gain experience needed to teach agricultural education. 


\section{TABLE OF CONTENTS}

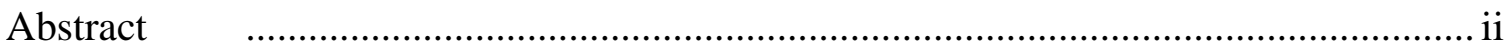

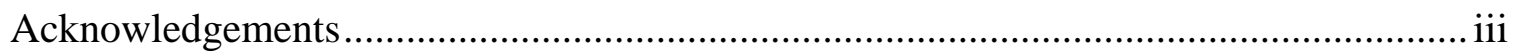

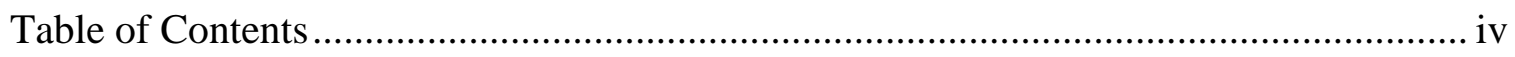

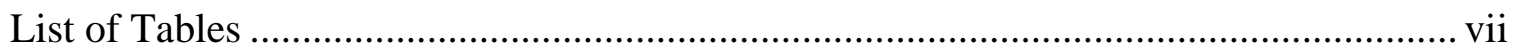

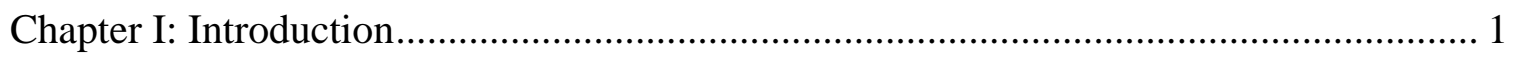

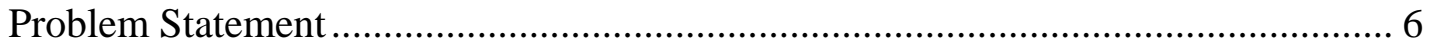

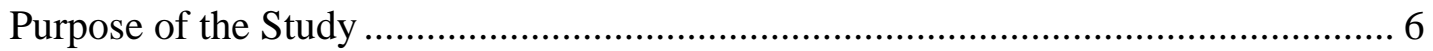

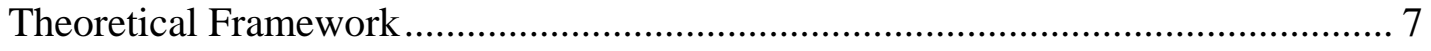

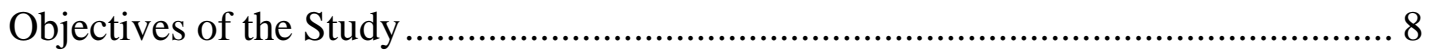

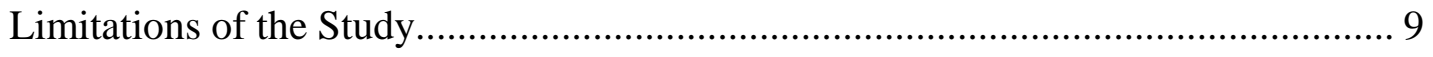

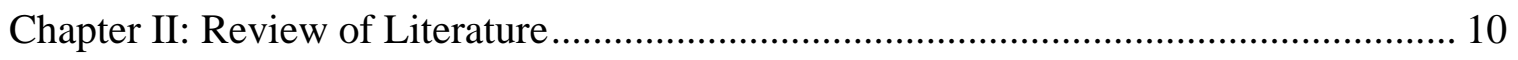

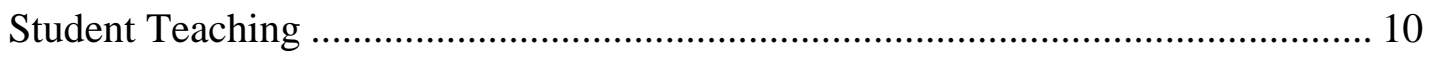

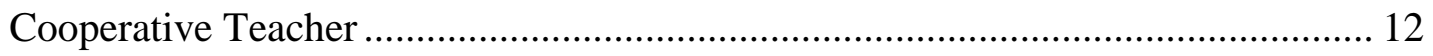

The Relationship between Both the Student Teacher and Cooperating Teacher...... 14

Suggestions to Eliminating the Challenges....................................................... 16

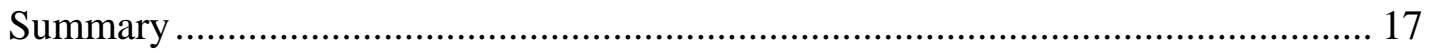

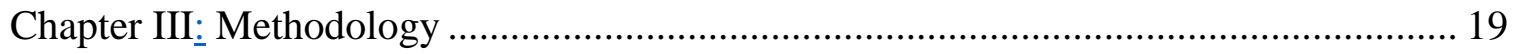

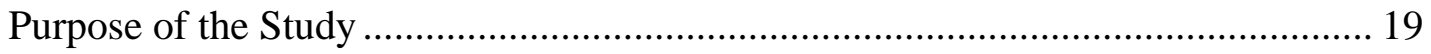

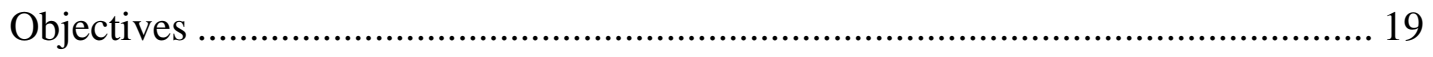

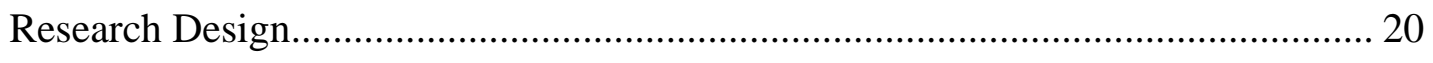

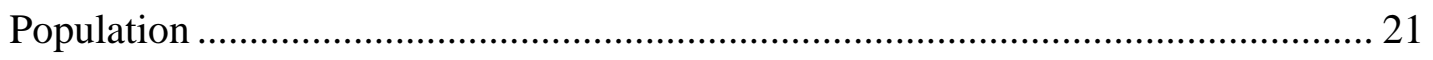

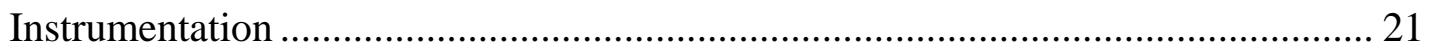

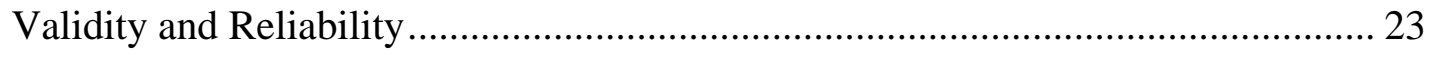

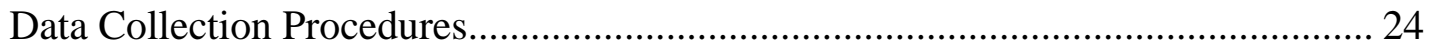


Analysis of Data.............................................................................................. 26

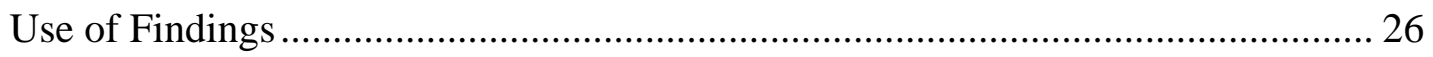

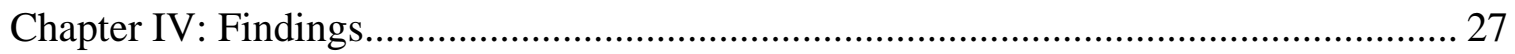

Purpose of the Study ............................................................................................ 27

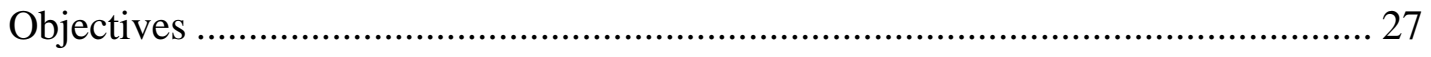

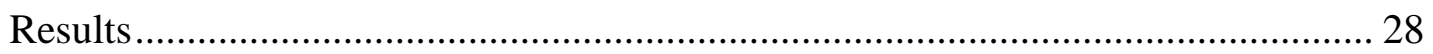

Demographic Characteristics of Respondents ......................................................... 28

Significance of Student Teacher Challenges ........................................................... 31

Frequency in which Student Teacher Challenges Occurred ..................................... 34

Student Teachers Knowledge Proficiency in Content Areas...................................... 41

Significance of Cooperating Teacher Challenges........................................................ 44

Chapter V: Summary, Conclusions, and Recommendations ............................................. 48

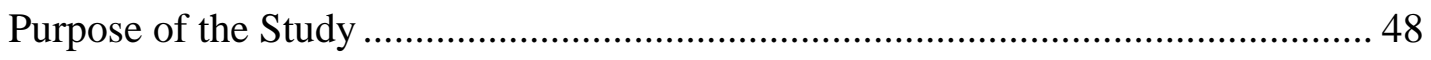

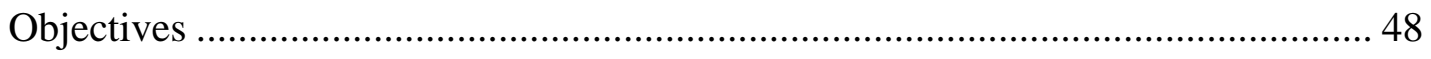

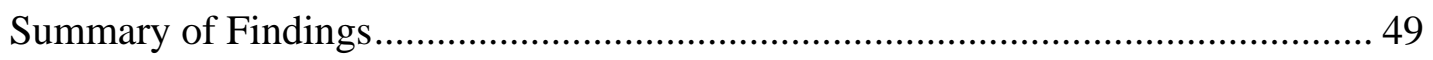

Challenges Cooperating Teachers Observed in Student Teachers ............................. 49

Content Knowledge of Student Teachers .................................................................. 50

Challenges Cooperating Teachers Faced Supervising a Student Teacher ................. 50

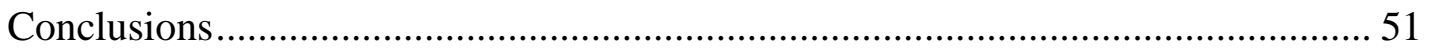

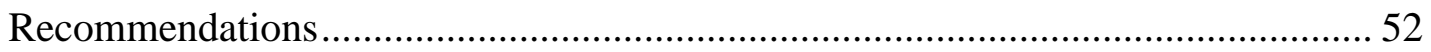

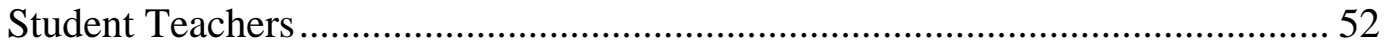

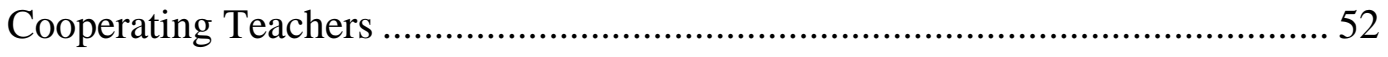

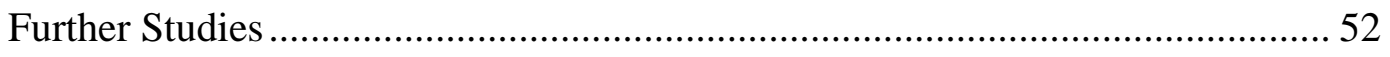

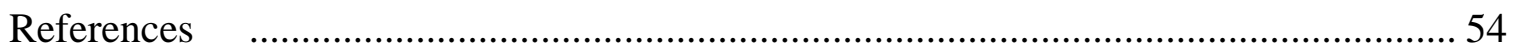

Appendix A: Phase I Survey ……………………………….................................... 58 


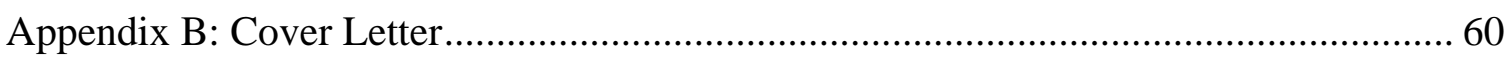

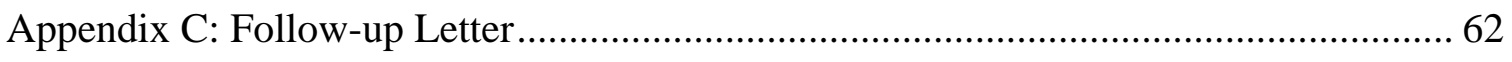

Appendix D:_Phase I Results ....................................................................................... 64

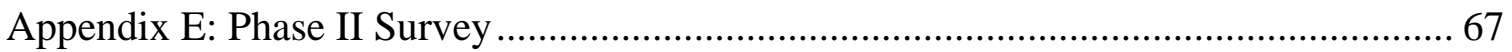

Appendix F: Phase II Cover Letter ................................................................................ 76

Appendix G: Phase II Results .................................................................................... 78

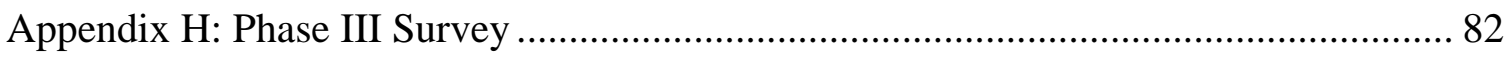

Appendix I: Cover Letter - Phase III............................................................................... 89

Appendix J: Follow-up Letter - Phase III......................................................................... 91

Appendix K: Second Follow-up Letter Phase III ............................................................... 93

Vita 


\section{LIST OF TABLES}

Table Title Page

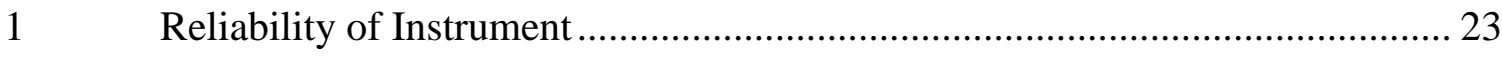

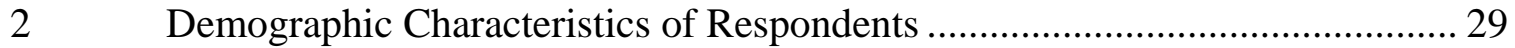

$3 \quad$ Open Ended Demographic Questions ......................................................... 31

$4 \quad$ Significance of the Problems Student Teachers Encountered ........................... 35

$5 \quad$ Frequency of the Problems Student Teachers Encountered ............................. 39

6 Student Teacher's Perceived Knowledge Proficiency in Content Areas........... 43

7 Significance of Problems Cooperating Teachers Encountered.......................... 45

8 Frequency of the Problems Cooperating Teachers Encountered ....................... 47 


\section{CHAPTER I}

\section{Introduction}

Student teaching is a common component in the preparation of public school teachers. Student teaching is defined as, "a period of guided teaching when a college student assumes increasing responsibility for directing the learning of a group of learners over a specific period of time” (Cardozier, 1967, p. 199). West Virginia Department of Education Policy 5100 6.4.b3 (2015) states, “all teacher candidates completing a WVBEapproved teacher preparation program for initial teacher licensure must complete a minimum of 125 clock hours of field experience” (p. 12).

The student teaching experience is not only different for each individual but differs between content areas and grade levels as well. Student teaching in an agricultural education classroom is very different from other content areas. The student teacher will encounter three main components. "The three components of agricultural education are classroom and laboratory, experiential learning through a supervised agricultural experience program (SAE), and leadership through FFA” (National FFA, 2016, p. 2). Classroom and laboratory is the first component because it is the most important and this is where high school students in the agricultural program spend the bulk of their time. The classroom is where students learn and gain the cognitive knowledge needed to understand the Agriculture content. The laboratory is where the students apply the knowledge they have learned from the classroom and use it in different laboratory settings such as; an agricultural mechanics, land laboratories, a greenhouse, a meats lab, and other facilities. The second component is experiential learning through a supervised agricultural experience program or SAE. The student either conducts research, is 
employed by an agricultural business, starts their own agricultural business, or can raise their own animals or plants. A SAE allows the student to practice the knowledge and skills learned in the classroom and laboratory by applying them to real world situations. The final component is leadership through the FFA, formerly known as the Future Farmers of America, it is now referred to as the National FFA Organization. This component is an intra-curricular activity for students enrolled in an agricultural education program and who have an SAE. The FFA focuses on, "premier leadership, personal growth, and career success in high school individuals” (National FFA, 2016, p. 2). It also offers opportunities for competition in agricultural related subjects, travel around the country for conventions, awards, degrees at different levels of success, and scholarships for future education. Individuals choosing to enter the agricultural education field encounter each of these three components when student teaching.

West Virginia University (WVU) supplies each student teacher with an instructional handbook. The handbook defines a student teacher as "a university senior or graduate student engaged in an internship in an assigned school under the supervision and guidance of the cooperating teacher and university supervisor" (West Virginia University Student Teacher Handbook, p. 3). Within the handbook the responsibilities are outlined for each individual involved in the student teaching experience. During the duration of student teaching the handbook includes the following to be the roles and responsibilities of the student teacher.

1. Conform to the standards of professional conduct as indicated in the handbook and by the administrator and cooperating teacher of the assigned school.

2. Restrict personal activities, including employment, in an effort to maximize student teaching effectiveness and efficiency.

3. Be punctual in attendance and performance of duties. 
4. Assist the cooperating teacher in regard to non-instructional duties and responsibilities to include serving on committees, attending faculty meetings, parent/teacher conferences, in-service days, and any other extracurricular aspects of the teaching experience.

5. Become familiar with the library/media center, health services, school resource specialists, community resources, clubs, emergency procedures, fire drill regulations, etc.

6. Adequately fulfill classroom responsibilities to include development of lesson plans, implementation of lesson plans, evaluation of pupil progress, and maintenance of constructive classroom management.

7. Fulfill the following University and school related responsibilities such as, attendance at University seminars applicable to the student teaching experience, document the student teaching experience through journal writing, inform cooperating teacher and university supervisor regarding any absence before the school day, file a valid tuberculosis test clearance with the placement coordinator, self-evaluation on a weekly basis, keep university supervisor abreast of classroom teaching schedule, complete a criminal background check. (WVU Handbook, n.d. p. 4)

The student teaching experience is not only a requirement for students but plays an important role in the plans for their future. Bacharach, Heck, and Dahlberg (2010) discussed the important role student teaching plays in becoming a certified teacher. The value of student teaching is clearly stated in their introduction, "in the world of teacher preparation, student teaching has long been the culmination of a teacher candidate's journey to becoming a licensed classroom teacher” (Bacharach et al., 2010, p. 3). “For most persons preparing to become teachers, student teaching or internship is the most valuable single experience they have in the teacher education program” (McGuire, Myers, \& Durrance, 1959, p. v). McGuire et al. (1959) provide helpful ideas and steps of what to do before, during, and after your student teaching experience.

In order for the student teacher to complete student teaching, receive their college degree, and teaching certification they need a cooperating teacher to assist and mentor them in the experience. A cooperating teacher or supervising teacher is defined as “a teacher of public school pupils who also directs the work of a student teacher” 
(Cardozier, 1967, p. 199). Cooperating teachers play a major role in the student teaching experience; West Virginia Department of Education Policy 5100 6.4.b3 (2015) notes that student teaching must occur "under the direction of a teacher licensed to teach in the state, by the state's authorized agency, or their university supervisor in which the field experience is occurring” (p. 12). West Virginia University also outlines the roles and responsibilities of the cooperating teacher. During the duration of student teaching the university expects the cooperating teacher to:

1. Become acquainted with needs, interests, and abilities of the student teacher.

2. Orient the student teacher to the teaching process by creating opportunities for observing and implementing effective teaching strategies, diagnosing and evaluating student progress, planning and developing lesson plans and content materials, and using efficient classroom management and organization.

3. Familiarize the student teacher with the policies, faculty, staff, and resources of the school.

4. Evaluate student progress by engaging in daily conferencing and documenting observations of the student teacher, giving student teacher written weekly progress forms, and participating in a joint conference with the university supervisor and the student teacher to complete a final narrative and additional required evaluations. (WVU Student Teacher Handbook p. 5)

Kasperbauer and Roberts (2007) noted the student teaching experience had a major impact on whether or not an individual chooses to enter the teaching field. They also indicate, "cooperating teachers are often the most influential aspect in the development of novice teachers" (p. 9). It is well documented that, "the student teaching center and the supervising (cooperating) teacher are the most important ingredients in the student teaching experience” (Norris, Larke, \& Briers, 1990, p. 58).

Student teachers gain valuable knowledge and a great experience from their cooperating teacher and the student teaching experience. "The student teaching 
experience holds great potential for impacting student teachers positively and setting them on a course of professional induction that is rewarding and purposeful" (Young \& Edwards, 2006, p. 90). Student teachers should "come away from the student-teaching experience with a positive attitude toward their chosen profession” (DeMoulin, 1993, p. 160). A study conducted by Smalley, Retallick, and Paulsen (2015) discovered the student teachers viewed "the most important activities in their capstone student teaching experience are related to planning for classroom instruction” (p. 87).

The cooperating teacher faces challenges during the experience. Paulson (2014) describes some challenges described by the cooperating teacher as a "lack of a presemester meeting, lack of planning time, having to give up control, poor quality of student-teacher dispositions, and lack of preparedness for teaching” (p. 41- 44). Early childhood cooperating teachers also identified challenges similar to these (Baum \& Korth, 2013). "Student teachers' discipline procedures, work ethic, time management skills, preparing student teachers to take full responsibility of the classroom, and lack of knowledge in some curriculum areas” (Fritz \& Mantooth, 2005, p. 54) were also viewed as challenges that agricultural education student teachers faced.

Some of these challenges can be addressed through daily and weekly conferences along with progress forms throughout the duration of the student teaching experience. The cooperating teacher can address the challenges with the final student teacher evaluation forms given at the end of the experience. Different schools and departments use different forms, which allow the cooperating teacher to formatively evaluate the student teacher each week and discuss improvements needed. Formative evaluation is defined as, "evaluation occurring before or during instruction; used to determine the 
starting point for instruction and provide feedback for students and teachers during the instruction” (Talbert, Vaughn, Croom, \& Lee, 2007, p. 514). Other forms are used for summative evaluation, which explain how the student teacher did throughout the entire duration of the student teaching experience. Talbert et al. (2007) defines summative evaluation as, "evaluation occurring after instruction, often in the form of a grade; can provide feedback to determine the next level at which a student should be placed and what changes can be made” (p. 523). The evaluation addresses the student teachers content knowledge, teaching methods, classroom management strategies, and overall professionalism. These forms provide the university supervisors with documentation related to the student teachers progress.

\section{Problem Statement}

Student teaching is a vital part needed for a student to become certified to teach at the public school level. In order to be able to student teach, university's need a certified individual in the public school system to supervise the preservice teacher and play the role of the cooperating teacher. There is limited data related to challenges which cooperating teachers encounter when supervising student teachers. This study was designed to identify the challenges cooperating teachers encountered when supervising a student teacher from the department of Agricultural and Extension Education at West Virginia University.

\section{Purpose of the Study}

The purpose of this study was to identify the challenges perceived by cooperating teachers when supervising student teachers from West Virginia University’s Agricultural and Extension Education department. This study will also address the significance of 
those problems and the frequency that they occurred with student teachers. This study will allow for the challenges to be identified and presented to West Virginia University’s Agricultural and Extension Education faculty. Once the faculty is informed of the challenges, solutions can be brainstormed to better prepare the student teacher and cooperating teacher before the student teaching experience begins. The study will also assist in providing data and information to teacher educators and state supervisors to improve the student teaching experience for both the cooperating teacher and student teacher.

\section{Theoretical Framework}

This study sought to identify the challenges cooperating teachers encounter. The Theory of Transformational Learning by Jack Mezirow provided the framework for this study. Mezirow (2000) noted, “a defining condition of being human is our urgent need to understand and order the meaning of our experiences, to integrate it with what we know to avoid the threat of chaos” (p. 3). This theory addresses how adult learners look at their experiences, reflect on them, and possibly change their learning.

Mezirow (1997) defines transformative learning as "the process of effecting change in a frame of reference” (p. 5). He also (goes on to say) "frames of reference are the structures of assumptions through which we understand our experiences” (p. 5). This helps us to conceptualize how individuals experience and think about certain things.

The student teacher experience closely relates to the Theory of Transformational Learning when you look at the reflection that takes place. Assuming that the student teacher is the adult learner in the situation, they will reflect on their experiences in the classroom and with the cooperating teacher to improve his/her teaching. Cooperating 
teachers play a role by assisting the student teachers as they reflect each day. The cooperating teacher can also share problems or situations they observe. Cooperating teachers can share knowledge and wisdom to student teachers as a means to eliminate the problems.

The Theory of Transformational Learning can also be applied by considering the cooperating teacher as the adult learner and this study is the facilitator or reflector. This study required cooperating teachers to reflect on their experiences with student teachers and identify common challenges. Once the challenges are identified it allows the cooperating teacher to adjust or "transform their learning" or process to help resolve the challenges.

\section{Objectives of the Study}

The objectives of this study were to identify what cooperating teachers perceive to be challenges when supervising a secondary Agricultural education student teacher from WVU.

The following questions provided direction for the study:

1. What did cooperating teachers perceive to be significant challenges for the student teachers they have supervised from West Virginia University’s Agricultural and Extension Education department between 2006-2016?

2. What did cooperating teachers perceive to be significant challenges they faced while supervising a student teacher from West Virginia University’s Agricultural and Extension Education department between 2006-2016?

3. How frequently have these challenges occurred with student teachers they have supervised between 2006-2016? 


\section{Limitations of the Study}

This study was limited to secondary agricultural educators who supervised student teachers for the West Virginia University agricultural education program from 20112016. 


\section{CHAPTER II}

\section{Review of Literature}

The review of literature produced four main factors relating to the student teaching experience. The first area addresses student teaching, the role of the student teacher, and the perceptions of the student teacher, with the second area addressing the same things only from the perception of the cooperating teacher. The third section identifies the importance of the relationship between both the student teacher and cooperating teacher and the fourth section provides suggestions to eliminating challenges the student teaching experience brings.

\section{Student Teaching}

Student teaching is a requirement for those who wish to receive certification to teach in the public school system. The West Virginia Department of Education Policy 5100 (2015) states in the introduction that those seeking to become certified teachers have to have a field experience. Student teachers in any content area have roles and responsibilities which tend to be similar across programs, states, or universities. Oregon State University notes in their handbook for secondary agricultural education student teachers some of the general instructions they are to follow, these include:

1. Student teachers in agricultural education are expected to devote their time to work and activities in the agriculture department during their student teaching period.

2. Be sure that everything you do is done to the best of your ability.

3. Set aside time at the end of each day for a conference with your cooperating teacher.

4. The local authorities have granted permission for you to observe and to do student teaching in their school. The continuance of this privilege to those who will follow you depends upon how well you do your work and the manner in which you conduct yourself. 
5. Develop an understanding of the ethics of the profession. As an example, you must recognize the confidential nature of personal data and treat it as such.

6. Report absence, due to any reason, to the cooperating teacher as soon as possible. Inform the university supervisor of any absence of this nature.

7. Be prepared to spend the time necessary to participate in the activities expected of agricultural education teachers. You are expected to take an active role in evening and weekend activities. (Oregon State, 2016, p. 4)

Each program and university has different requirements for student teachers but the roles and responsibilities are similar. A student teacher is expected to act professional, provide a class of pupils with knowledge needed for the content area, and take the role of the regular teacher in lesson planning, instruction, classroom management, and other activities outside of class time.

The college or university program the students are enrolled in helps to prepare them with teaching and content skills needed for the student teaching experience. Bacharach, Heck, and Dahlberg (2010) states the "student teaching experience is the most prevalent way in which colleges and universities link the theory of educational preparation with the reality of daily classroom practice” (p. 3). Smalley, Retallick, and Paulsen (2015) gathered data from student teachers in a qualitative study to see if they felt the knowledge they learned from their program was useful or "relevant” to student teaching. The authors concluded the skills such as, activities for planning instruction, activities geared towards teaching, performance activities, and FFA/SAE activities were either found to be “very relevant or relevant” (p. 77).

Student teachers are not only prepared for a future in education by their university or college experience but by their cooperating teacher as well. Student teachers look to the cooperating teacher to be a mentor and to guide them through the experience. When it 
comes to the role mentoring plays, one study documented the student teachers' outlook on the five factors of mentoring, which include, "personal attributes, system requirements, pedagogical knowledge, modeling, and feedback,” (Bird, 2012, p. 39) and the effect they had on the student teachers experience. The author noted, "the results support the importance of the five factors of mentoring that were perceived by student teachers to have an impact on their success during student teaching” (Bird, 2012, p. 56). McGuire, Myers, and Durrance (1959) discusses main points for a student teacher to consider which will help them really benefit from the student teaching experience. It provides clarity related to what the prospective student teacher should do before they start student teaching, during, and after. McGuire et al. (1959) outlines the expectations, anxieties, and suggestions for getting to know everyone and everything before the student teaching experience. It also provides instruction for planning, developing, and assisting student during the experience and ends by documenting how to evaluate your work, self, and your future as a teacher.

\section{Cooperative Teacher}

The cooperative teacher plays a major role in student teaching as well. West Virginia Department of Education Policy 5100 (2015) dictates that the field experience must be done with a state licensed teacher. Not only is the cooperating teacher needed to supervise the student teacher but they too have a role with responsibilities, which they follow. These roles and responsibilities are roughly the same across university agricultural education programs. Purdue University’s Agricultural Education Department outlines what they consider to be the role and responsibilities of a cooperating teacher in 
their Cooperating Teacher Handbook. Some of the roles and responsibilities are as follows:

1. Role of the cooperating teacher, wear many hats: that of a master teacher, guidance counselor, master planner and organizer, sympathetic father or mother.

2. Responsibilities include: a willing cooperator.

3. Prepare class for student teacher's arrival.

4. Orient student teacher to students, classroom, school, and community.

5. Find ways for student teacher to assist in classroom as soon as possible.

6. Help student teacher assume full-time teacher role.

7. Provide frequent encouragement, constructive criticism, and recognition of success.

8. Keep records and evaluation reports of student teacher progress and general promise as a teacher. (p. 10)

Literature discovered during this study provided other studies related to the effects the student teaching experience had on the cooperating teacher. Paulson (2014) investigated the effects the student teaching experience had on cooperating teachers and examined the relationship between the cooperating teacher and the student teacher. Paulson's study found that the following were issues the cooperating teacher faced during the experience, “the cooperating teachers' lack of preparation for the semester, a need for better selection of student teachers, cooperating teachers' desire for feedback, roles of the cooperating teacher, and cooperating teachers' desire for power and respect” (2014, p. 98). Paulson (2014) goes on to explain each of these factors and stated that the belief of the cooperating teacher was that the university did not fully prepare the student teachers, they were not fully prepared to have a student teacher, and that university and college program departments should be more selective in the individuals they send out to student teach. Paulsen went on to explain there was a desire for better outlined roles and responsibilities for cooperating teachers to follow as they supervised the student teacher. Not all outcomes of the student teaching experience had a negative effect on the cooperating teacher. 
Mecca (2010) looked at the changes in teacher's professional development due to having a student teacher, the population were teachers of various subjects and backgrounds. The results stated "the overarching finding was that 11 of the 12 cooperating teachers indicated the experience had a positive impact on their practice” (Mecca, 2010, p. 141). The researcher also went on to say that "the major positive impact on the practice of 11 of the 12 teachers was the learning of new innovative teaching methods and techniques” (Mecca, 2010, p. 141).

Edwards (2012) findings were based on individuals who served as cooperating teachers during the spring semester of 2012 for agricultural education students and discussed "the effects of the student teaching experience on the cooperating teacher" (p. 3). He found the results to fit into, "4 themes, professional identities affected by membership in pre-service community, they volunteer to help others and themselves, empower themselves and other in the community through leadership, and professional practices influenced by their service as a cooperating teacher” (Edwards, 2012, p. 147).

Not all the literature reviewed was related to secondary education or agricultural education. One study was related to early childhood education and was conducted to see if and how teachers were prepared to be cooperating teachers. The study found, "teacher preparation programs and cooperating teachers must become collaborative partners and identify shared goals and expectations for the roles and responsibilities of all involved" (Baum \& Korth, 2013, p. 188).

\section{The Relationship between Both the Student Teacher and Cooperating Teacher}

The experience of student teaching is not just about the student teacher but, about the cooperating teacher, their relationship, and the setting of the experience. Young and 
Edwards (2006) studied secondary agricultural education cooperating teachers and student teachers to discover that cooperating teachers and student teachers rated “Cooperating Teacher-Student Teacher Relationships" as the most important core area of the student teaching experience.

Kasperbauer and Roberts (2007) conducted research on pre-service teachers in agricultural education at Texas A\&M University to determine if a student teacher’s decision to enter the field of teaching was determined by their relationship with the cooperating teacher. Results concluded that "the student teaching/cooperating teacher relationship is not predictive of their decision to teach. However, results indicated that the student teacher/cooperating teacher relationship is important to student teachers” (Kasperbauer \& Roberts, 2007, p. 16).

Not only are relationships important in the experience but the setting of the experience along with the entire experience play a role. Norris et al. (1990) conducted a study to investigate the ideal setting compared to where student teachers were conducting their experience. The findings stated that student teachers, "have higher ideals for characteristics and procedures for their programs than what exists” (Norris et al., 1990, p. 63)

Schumann, (1969) an agriculture teacher in Texas said, "if the student teachers is to develop desirable teaching skills and personal habits, the guidance and supervision of the cooperating teacher is imperative” (p. 156). He broke student teaching into the following three steps: orientation, participation, and supervision. The student teacher should learn the policies and rules of the school through an orientation with the cooperating teacher. The student teacher should immerse themselves into the program 
and participate in all that student teaching has to offer. The cooperating teacher should provide feedback and guidance along with having the student teacher evaluate their own performance in the supervision step. The student teaching experience as a whole cannot happen without both the student teacher and the cooperating teacher. Due to the fact that both are needed, the relationship between the two is important.

\section{Suggestions to Eliminating the Challenges}

Where there is a problem or challenge there is always a solution, or at least a suggestion for how it can be eliminated. Some literature provided tips and suggestions to get the student teaching experience off on the right foot. The common occurrence among the readings was the fact that they discussed cooperating teachers gathering to deliberate the role that each individual would play in the experience. They also addressed any questions or concerns that cooperating teachers might have going into the supervision of a student teacher.

The University of Illinois held a conference, "for the purpose of strengthening the student teaching phase of the undergraduate training program for teachers of vocational agriculture in Illinois” (Atherton, 1950, p. 95). The conference not only occurred in the

middle of a student teaching term but in the middle of the week as well. The logic behind this was to provide enough time to identify the problems or concerns of the cooperating teacher and left the student teacher in charge of the class in the cooperating teachers' absence.

Khuns, (1972) a student teacher from the University of Illinois made a list of "did you knows” and other suggestions for cooperating teachers. The list helped address issues from the student teachers point of view. A few examples are, "Did you know that a 
student teacher sees the teaching profession through your eyes?" and "Get the student teacher involved in all phases of teaching. He needs experience with advisory groups, FFA, classroom teaching, adult programs, placement, etc.” (p. 41).

Bradley (1974) discussed Kansas State University’s seminar which helped to address the frequently asked questions about the experience of being a cooperating teacher and having a student teacher to supervise. The result of this seminar was that, "this was the way Kansas cooperatively planned and proceeded to improve the preparation of cooperative teachers in vocational agriculture” (Bradley, 1974, p. 69).

\section{Summary}

The review of literature was broken into four sections. The first one discussed student teachers, their views, and feelings related to the student teacher experience. The second section focused on cooperating teachers, their views, and feeling on the student teaching experience. The third section looked at literature, which addressed both the student teacher and the cooperating teacher along with the relationship between the two. The final section addressed possible solutions to eliminating the challenges and problems.

The literature noted what student teachers learn from their undergraduate program can be applied to the experience and the mentoring they receive from their cooperating teacher prepares them for the future. The literature also documented the importance of the cooperating teacher. Cooperating teachers think the student teaching experience not only helps the student teacher but it allows them to share what they know and have experience.

The literature not only documented the importance of student teaching, but the importance of the relationship between the student teacher and the cooperating teacher as individuals. The literature clarified how all the components of the student teaching 
experience not only play a role but how they relate to one another. The literature allowed a look into the past of how other universities have addressed the issues and concerns of cooperating teachers through seminars and meetings. The student teaching experience is so important that universities, cooperating teachers, and student teachers need to make sure that all of these elements are present for it to be successful. 


\section{CHAPTER III}

\section{Methodology}

\section{Purpose of the Study}

The purpose of this study was to identify the challenges secondary agricultural cooperating teachers perceived their student teachers to face, the significance of those challenges, and the frequency in which they occurred. This study also set out to identify the challenges that the cooperating teachers perceived themselves to encounter when supervising a student teacher, the significance of those challenges and the frequency in which they occurred. Data will allow the challenges to be identified and shared with teacher educators, state supervisors, and department faculty to better prepare student teachers and cooperating teachers.

\section{Objectives}

The objectives of this study were to identify what cooperating teachers perceive to be challenges when supervising a secondary Agricultural education student teacher from WVU.

The following questions provided direction for the study:

1. What did cooperating teachers perceive to be significant challenges for the student teachers they have supervised from West Virginia University’s Agricultural and Extension Education department between 2006-2016?

2. What did cooperating teachers perceive to be significant challenges they faced while supervising a student teacher from West Virginia University’s Agricultural and Extension Education department between 2006-2016? 
3. How frequently have these challenges occurred with student teachers they have supervised between 2006-2016?

\section{Research Design}

The research design used was a modified Delphi, using three phases, "Delphi may be characterized as a method for structuring a croup communication process so that the process is effective in allowing a group of individuals, as a whole, to deal with a complex problem” (Linstone \& Murray, 1975, p. 3). Each phase consisted of a descriptive survey, "Surveys permit the researcher to summarize the characteristics of different groups or to measure their attitudes and opinions toward some issue” (Ary, Jacobs, Sorensen, \& Walker, 2014, p. 30). The first part of the data collection was Phase I, a mailed survey with two open-ended questions. Once the respondents returned the survey, the statements were reviewed and combined without changing the original meaning, creating the Phase II instrument. Phase II was a mailed questionnaire comprised of closed ended questions either with the respondents answering "yes" or "no" on whether or not they agreed with the statement comprised from Phase I. The third and final phase was constructed after Phase II was returned and analyzed. It included closed ended questions with a Likert type scale where the population rated the statements on significance and frequency. The statements included the statements from Phase II that 52\% or more of the respondents agreed with. Ary et al. (2014) did list the advantages and disadvantages of a mailed survey. They consider some of the advantages to be, "allows anonymity, no interviewer bias, and convenience" while stating the disadvantages to be, "slow process, low response rate, cannot clarify question, and literacy required” (Ary et al., 2014, p. 414). 
During Phase I and Phase II, respondents were given the option to provide their email address so that the surveys that followed could be taken electronically.

\section{Population}

The target population was secondary agricultural educators who have served as cooperating teachers for student teachers from the Agricultural and Extension Education (AGEE) department at West Virginia University within the past 5 years. The population was accessible via the West Virginia Agricultural Educator Directory updated annually by the West Virginia University Agricultural and Extension Education faculty. The population included 53 individuals who fit the criteria. The mailed and electronic surveys were coded so non-respondents could be identified but the individuals stayed anonymous. The population was acquired through a census in order to address sampling error.

\section{Instrumentation}

The instrument was a modified Delphi with three phases of descriptive surveys. Phase I contained two open-ended questions, the first question asked cooperating teachers to list up to three challenges they observed their student teachers face during the student teaching experience. The second question asked the cooperating teachers to list up to three challenges they found themselves encounter while supervising a student teacher. Each cooperating teacher was asked to keep their responses limited to the student teachers they have supervised from West Virginia University’s AGEE department between 2006-2016. Once the survey was returned and analyzed the responses were placed into categories of similarity, the categories provided organization in creating the second survey. Phase II then asked the population whether they "agreed” or "disagreed" with the responses given in Phase I. Phase II was then returned and analyzed and those 
statements that $52 \%$ or more of respondents agreed to were used in the final survey. Phase III was split into four different sections. The first section related to challenges they cooperating teachers identified the student teachers encountering during the student teaching experience. The respondents were asked to answer using a Likert type scale 1-5 to rate the significance of the problem: 1- not applicable, 2- not a problem, 3- minor problem, 4- moderate problem, 5- serious problem. They also had to rate each problem on the frequency it occurred using a 1-5 Likert type scale: 1- not applicable, 2- never, 3occasionally/sometimes, 4- almost every time, 5- every time. The second section of the survey asked the cooperating teacher to rate the average content area proficiency of the student teachers they supervised between 2006-2016. The content areas listed were agricultural mechanics, agricultural business, FFA/SAE, food/meat science, large animal science, small animal science, forestry, natural resources, plant science, soil science, and greenhouse management. They rated these on a scale of 1-5: 1- not applicable, 2- not proficient, 3- somewhat proficient, 4- moderately proficient, 5- extremely proficient. The third section was identical to the first, the only difference is the statements were related to challenges that the cooperating teachers identified themselves encountering during the student teacher experience. They used the same Likert type scale to rate both the significance and the frequency of that problem. The fourth and final section was the demographics section in order to describe the respondents. They were asked their gender, age category, highest obtained degree, years of teaching experience, average number of students in the program, number of teachers in the department, and the number of student teachers they have supervised from West Virginia University’s Agricultural and Extension Education (AGEE) department between 2006-2016. 


\section{Validity and Reliability}

Validity was established to ensure that accurate results could be reported. A panel of experts, which consisted of professors in the West Virginia University AGEE department, established face and content validity of the instrument. Once validity was established, reliability was established using a split-half analysis using data from the final survey. A Spearman-Brown coefficient was calculated for the student teacher problems section, content knowledge section, cooperating teacher section, and all the sections together (see Table 1). All parts were considered “exemplary” in reliability (Robinson, Shaver, \& Wrightsman, 1991). The results of the reliability test were, student teacher problems $($ Spearman-Brown = .959), content knowledge $($ Spearman-Brown $=.867)$, cooperating teacher problems $($ Spearman-Brown $=.738)$, and all the sections (SpearmanBrown $=.672)$.

Table 1

Reliability of Instrument

Spearman-Brown

\begin{tabular}{lcc} 
Construct & Coefficient & Reliability \\
\hline Student Teacher Problems & .959 & Exemplary \\
Content Knowledge & .867 & Exemplary \\
Cooperating Teacher Problems & .738 & Exemplary \\
All Sections & .672 & Exemplary \\
\hline
\end{tabular}




\section{Data Collection Procedures}

The data collection process mirrored that of The Dillman Total Design Survey (Dillman, Smyth \& Christian, 2009) in order to receive a good response rate. Collection started by sending the population a cover letter explaining the study and reasons as to why their response was important. The population also received a packet, which included the survey and a return envelope already stamped and addressed. The surveys and return envelopes were coded and kept in a safe place in order to keep track of non-respondents while allowing the respondents to stay anonymous. Once the deadline had passed, another packet was sent to the non-respondents with another cover letter, survey, return envelope, and a new deadline.

Once the collection of Phase I was complete it was analyzed and used to create Phase II. The responses from Phase I were all placed into a spread sheet that was color coded in order to categorize statements based on similarity (see Appendix for Phase I responses). Similar statements were also combined in order to eliminate having the same statement a number of times. This process produced 90 statements for Phase II. The population was asked during Phase I to please include an email address to take the next two phases electronically. Distribution of Phase II included another mailed packet with a new cover letter, second survey, and return envelope. There was also an electronic version sent to part of the population with an emailed cover letter and Qualtrics survey link. Once the initial deadline passed, another packet was sent to non-respondents along with a reminder email to those participating electronically.

Phase II was then analyzed and used to construct Phase III. The statements from Phase II were sorted in order to identify the number of respondents that agreed with each 
statement versus those who disagreed. The statements $52 \%$ or more of the respondents agreed with were used in to Phase III. The third phase allowed the population to rate the significance and the frequency of the problems identified in Phase I \& II. This phase also allowed for the population to be described through demographic characteristics. Phase III was mailed with a packet including a cover letter, the final survey, and return envelope. There was also a cover letter sent via email and a Qualtrics survey link to the population that supplied email addresses. Once the first deadline passed, another mailed packet was sent along with a reminder via email. When the second deadline passed a third follow-up mailing occurred. Once three attempts for contact had been made to all non-respondents the data was analyzed from the final phase.

In order to address the non-response error, early and late respondents from Phase III were compared. Miller and Smith (1983) stated, "research has shown that late respondents are often similar to non-respondents” (p. 48). Both were compared using the following three variables: years of experience, number of students in the program, and number of student teachers they have supervised between 2006-2016. A Chi-Square statistical analysis was conducted to compare early and late respondents to their years of experience teaching and there was no significance found between the two. A T-Test statistical analysis was used to compare early and late respondents to the number of students in their program as well as the number of student teachers they have supervised. The two analyses also showed no significance. Seeing that there was no significant difference between the early and late respondents thus, the findings were generalized to the entire population in the study. 


\section{Analysis of Data}

The first phase was analyzed by placing all the responses into categories and combining those that discussed the same idea. The second phase was analyzed but calculating the percent of respondents that answered yes to each statement. The statements that $52 \%$ or more of the respondents agreed to were used for Phase II. The third phase was analyzed using SPSS to calculate frequencies and percent.

\section{Use of Findings}

The findings were used to identify the common challenges which cooperating teachers supervising student teachers from West Virginia University’s AGEE department face. Results were also used to identify the challenges cooperating teachers feel that student teachers encounter during the student teaching experience. The results allowed the frequency and significance of those problems to be identified. The results could possibly lead to workshops or training to prepare future cooperating teachers. Results also lead to support and help for the cooperating teachers in order to minimize the challenges in the future. 


\section{CHAPTER IV}

\section{Findings}

\section{Purpose of the Study}

The purpose of this study was to identify the challenges secondary agricultural cooperating teachers perceived their student teachers to face, the significance of those challenges, and the frequency in which they occurred. This study also set out to identify the challenges that the cooperating teachers perceived themselves to encounter when supervising a student teacher, the significance of those challenges and the frequency in which they occurred. Data will allow the challenges to be identified and shared with teacher educators, state supervisors, and department faculty to better prepare student teachers and cooperating teachers.

\section{Objectives}

The objectives of this study were to identify what cooperating teachers perceive to be challenges when supervising a secondary Agricultural education student teacher from WVU.

The following questions provided direction for the study:

1. What did cooperating teachers perceive to be significant challenges for the student teachers they have supervised from West Virginia University’s Agricultural and Extension Education department between 2006-2016?

2. What did cooperating teachers perceive to be significant challenges they faced while supervising a student teacher from West Virginia University’s Agricultural and Extension Education department between 2006-2016? 
3. How frequently have these challenges occurred with student teachers they have supervised between 2006-2016?

\section{Results}

The responses from Phase I produced 90 statements to appear in Phase II for respondents to either agree or disagree with. Phase III was then comprised of the statements in Phase II that 52\% or more of the respondents agree to be a problem. Phase II produced 13 statements addressed to challenges of the student teacher and three statements addressed to challenges of the cooperating teacher. The following tables and data are associated with the respondents from Phase III only.

The population was comprised of secondary agricultural educators who have served as a cooperating teacher between 2011-2016 for West Virginia University’s AGEE department. The total population for the study was 53 cooperating teachers the final response rate from Phase III was 55\% (n = 29). Early and late respondents from Phase III were compared, the statistical analysis showed no significant data, therefore we can generalize the results to the entire population. Reliability was determined using a split-half statistical analysis and the Spearman-Brown coefficient values were considered exemplary (Robinson, Shaver, \& Wrightsman, 1991).

\section{Demographic Characteristics of Respondents}

The population was asked several demographical characteristic questions describing them (see Table 2). The population was asked which gender they identified with, 78.57\% ( $f=22$ ) of respondents identified as being male, while $21.43 \%(f=6)$ identified as female. When asked to identify their age category, 3.57\% $(f=1)$ fell into the 25-29 years of age category, with $7.14 \%(f=2)$ in the $30-34$ and $40-44$ years of age 
ranges. Four (14.29\%) respondents identified as being in the 35-39 years of age category, with $10.71 \%(f=3)$ being in the $45-49$ age range, and the majority of respondents 57.14 ( $f=16)$ identified themselves to be 50 years or older.

The third demographic question asked the population what their highest obtained degree currently is. There were $14.29 \%(f=4)$ who identified as having a Bachelors degree, $82.14 \%(f=23)$ who responded to having a Masters degree, and 3.57\% $(f=1)$ who had a Doctorate degree. The cooperating teachers were also asked to identify the range that best represented their years of teaching experience. None of the cooperating teachers had less than 5 years of teaching experience, $10.71 \%(f=3)$ of the respondents had either 5-9, 10-14, or 15-19 years of teaching experience, and $67.86 \%(f=19)$ of the cooperating teachers had 20 or more years of teaching experience.

Table 2

Demographic Characteristics of Respondents

\begin{tabular}{ccc}
\hline & $f$ & $\%$ \\
\hline Gender & 22 & 78.57 \\
Male & 6 & 21.43 \\
Female & & \\
Age Category & 1 & 3.57 \\
$25-29$ & 2 & 7.14 \\
$30-34$ & 4 & 14.29 \\
$35-39$ & 2 & 7.14 \\
$40-44$ & 3 & 10.71 \\
$45-49$ & 16 & 57.14 \\
$50+$ & & \\
\hline
\end{tabular}


Table 2 (continued)

Demographic Characteristics of Respondents

\begin{tabular}{lcc}
\hline & $f$ & $\%$ \\
\hline Highest Obtained Degree & & \\
Bachelors & 4 & 14.29 \\
Masters & 23 & 82.14 \\
$\quad$ Doctorate & 1 & 3.57 \\
Years of Teaching Experience & & \\
Less than 5 & 0 & .00 \\
5-9 & 3 & 10.71 \\
$10-14$ & 3 & 10.71 \\
$15-19$ & 3 & 10.71 \\
$20+$ & 19 & 67.86 \\
\hline
\end{tabular}

Note. $\mathrm{n}=28$

The cooperating teachers were also asked three open-ended or numerical option questions, with the first asking the amount of students in their agricultural program. The mean was 133.58 with a standard deviation of 47.87 , the minimum amount of students in a program was 50 and the maximum was 250 students. The second question asked the individuals how many teachers were in their agricultural department. The mean was determined to be 1.79 with a standard deviation of 0.79 ; the minimum number of teachers reported was one where the maximum number of teachers in a department was four. The final question asked the cooperating teachers to identify the number of student teachers they had supervised between 2006-2016 from West Virginia University’s Agricultural and Extension Education department. The mean was found to be 4.36 with a standard 
deviation of 3.18. Cooperating teachers observed a minimum of one student teacher during 2006-2016, while the maximum was 12 student teachers supervised.

Table 3

Open Ended Demographic Questions

\begin{tabular}{lcccc}
\hline Question & $M$ & $S D$ & Minimum & Maximum \\
\hline $\begin{array}{l}\text { On average, what is the } \\
\text { number of students in your } \\
\text { program? }\end{array}$ & 133.58 & 47.87 & 50 & 250 \\
$\begin{array}{l}\text { How many teachers are in } \\
\text { your agricultural department? }\end{array}$ & 1.79 & .79 & 1 & 4 \\
$\begin{array}{l}\text { How many student teachers } \\
\text { did you supervise between }\end{array}$ & & & & \\
2006-2016? & 4.36 & 3.18 & 1 & 12 \\
\hline
\end{tabular}

\section{Significance of Student Teacher Challenges}

The cooperating teachers were then asked to answer a series of questions related to problems they perceived their student teachers encountering. The cooperating teachers were asked to rate the significance of the problems on a scale 1-5; 1- not applicable, 2not a problem, 3- minor problem, 4- moderate problem, 5- serious problem (see Table 4).

The first identified problem related to the student teachers was their classroom management, none of the respondents found this statement to be not applicable, while 20.69\% $(f=6)$ considered it not a problem, and 48.28\% $(f=14)$ responded it was a minor problem. Cooperating teachers who considered classroom management to be a moderate problem were $31.03 \%(f=9)$, while none of them found it to be a serious problem. The second statement addressed the student teachers ability to handle discipline problems when they arose. Once again none of the cooperating teachers perceived the problem to 
be not applicable, however $17.24 \%(f=5)$ rated it as not a problem, 58.62\% $(f=17)$ rated it as a minor problem, $31.03 \%(f=9)$ rated it as a moderate problem, and none of the cooperating teachers perceived it to be a serious problem. When asked the significance of their student teacher not having a strong discipline plan in place, 3.57\% $(f=1)$ found it to be not applicable, $17.86 \%(f=5)$ considered it not a problem. Fourteen (50\%) said it was a minor problem, $28.57 \%(f=8)$ perceived it to be a moderate problem, and none of the cooperating teachers identified it as a serious problem.

The population was then asked how significant they perceived the problem of their student teachers ability to handle students who did not want to be in class. Of the respondents 3.45\% $(f=1)$ found the problem to be not applicable, 34.48\% $(f=10)$ rated it not a problem, $37.93 \%(f=11)$ considered it a minor problem, $24.14 \%(f=7)$ said it was a moderate problem, and none of the respondents considered it a serious problem. When asked about the student teachers time management none of the respondents found it to be not applicable, however $34.48 \%(f=10)$ said it was not a problem, $31.03 \%(f=9)$ rated it a minor problem, $34.48 \%(f=10)$ considered it to be a moderate problem, while none of the respondents perceived it to be a serious problem. None of the respondents considered the problem of their student teachers' total time commitment to the job to be not applicable. However, $37.93 \%(f=11)$ said it was not a problem or it was a minor problem, $17.24 \%(f=5)$ considered it a moderate problem, and $6.90 \%(f=2)$ rated it as a serious problem.

Next was the problem about student teachers lesson preparation, none of the respondents found it to be not applicable, while $35.71 \%(f=11)$ said it was not a problem, 50\% $(f=14)$ rated it a minor problem, $10.71 \%(f=3)$ found it as a moderate 
problem, and 3.57\% $(f=1)$ said it was a serious problem. Ability to keep up with WVU level lesson plans was rated by zero respondents as not applicable, 39.29\% $(f=11)$ rated it as not a problem, 32.14\% $(f=9)$ said it was a minor problem, while $25 \%(f=7)$ considered it to be a moderate problem, and 3.57\% $(f=1)$ said it was a serious problem. Student teachers ability to keep students engaged was considered not applicable by zero respondents, but $24.14 \%(f=7)$ said it was not a problem, $65.52 \%(f=19)$ considered it a minor problem, $10.34 \%(f=3)$ rated it as moderate, while none of the respondents considered it to be a serious problem.

Cooperating teachers were then asked about the significance of their student teachers ability to teach students with different skill levels. Of the respondents none perceived it to be not applicable, $17.24 \%(f=5)$ said it was not a problem, $65.52 \%(f=$ 19) considered it to be a minor problem, $10.34 \%(f=3)$ rated it as a moderate problem, and $6.90 \%(f=2)$ rated it as a serious problem. Student teachers ability to differentiate instruction was perceived as not applicable to zero respondents, while 31.03\% $(f=9)$ said it was not a problem, $51.72 \%(f=15)$ rated it as a minor problem, $10.34 \%(f=3)$ considered it a moderate problem, and 6.90\% $(f=2)$ rated it as a serious problem. Student teachers lack of record book knowledge was considered not applicable by $3.45 \%(f=1)$ of respondents, while $20.69 \%(f=6)$ said it was not a problem, $48.28 \%(f=14)$ rated it as a minor problem, $17.24 \%(f=5)$ found it to be a moderate problem, and $10.34 \%(f=3)$ considered it to be a serious problem. The last question related to the student teachers, asked about the significance of their lack of knowledge in agricultural mechanics. Of the respondents, $6.90 \%(f=2)$ rated it as not applicable, $17.24 \%(f=5)$ perceived it to not be 
a problem, $44.83 \%(f=13)$ considered it to be a minor problem, while $13.79 \%(f=4)$ said it was a moderate problem, and $17.24 \%(f=5)$ rated it as a serious problem.

\section{Frequency in which Student Teacher Challenges Occurred}

Once the significance of each problem was identified, the cooperating teachers were asked to identify the frequency in which those problems occurred in their student teachers (see Table 5). The first problem to rate on frequency was the student teachers classroom management, none of the respondents found this statement to be not applicable, while $14.81 \%(f=4)$ said it never occurred and $70.37 \%(f=19)$ responded that the problem occurred occasionally/sometimes. Cooperating teachers who considered classroom management to be a problem that occurred almost every time were $11.11 \%$ ( $f$ = 3), while 3.70\% $(f=1)$ perceived it to be a problem that occurred every time. The second statement addressed the student teachers ability to handle discipline problems when they arose. Once again none of the cooperating teachers perceived the problem to be not applicable, however 7.69\% $(f=2)$ rated it never a problem, $80.77 \%(f=21)$ responded to it as occasionally/sometimes, 7.69\% $(f=2)$ said it occurred almost every time, and 3.85\% $(f=1)$ said it occurred every time. When asked the frequency of their student teacher not having a strong discipline plan in place, zero found it to be not applicable, $8 \%(f=2)$ considered it to never happen, $72 \%(f=18)$ said it was occasionally/sometimes, $12 \%(f=3)$ perceived it to be almost every time, and $8 \%(f=2)$ said it occurred every time. 
Table 4

Significance of the Problems Student Teachers Encountered

\begin{tabular}{|c|c|c|c|c|c|c|c|c|c|c|c|}
\hline \multirow[b]{2}{*}{ Problems } & \multirow[b]{2}{*}{$n$} & \multicolumn{2}{|c|}{ N/A } & \multicolumn{2}{|c|}{ Not a Problem } & \multicolumn{2}{|c|}{ Minor Problem } & \multicolumn{2}{|c|}{$\begin{array}{l}\text { Moderate } \\
\text { Problem }\end{array}$} & \multicolumn{2}{|c|}{ Serious Problem } \\
\hline & & $f$ & $\%$ & $f$ & $\%$ & $f$ & $\%$ & $f$ & $\%$ & $f$ & $\%$ \\
\hline Classroom management & 29 & 0 & .00 & 6 & 20.69 & 14 & 48.28 & 9 & 31.03 & 0 & .00 \\
\hline $\begin{array}{l}\text { Knowing how to handle } \\
\text { discipline problems when } \\
\text { they arise }\end{array}$ & 29 & 0 & .00 & 5 & 17.24 & 17 & 58.62 & 7 & 24.14 & 0 & .00 \\
\hline $\begin{array}{l}\text { Not having a strong } \\
\text { discipline plan in place }\end{array}$ & 28 & 1 & 3.57 & 5 & 17.86 & 14 & 50.00 & 8 & 28.57 & 0 & .00 \\
\hline $\begin{array}{l}\text { Not being prepared to } \\
\text { handle secondary students } \\
\text { who did not want to be in } \\
\text { the class }\end{array}$ & 29 & 1 & 3.45 & 10 & 34.48 & 11 & 37.93 & 7 & 24.14 & 0 & .00 \\
\hline Time management & 29 & 0 & .00 & 10 & 34.48 & 9 & 31.03 & 10 & 34.48 & 0 & .00 \\
\hline $\begin{array}{l}\text { Total time commitment to } \\
\text { the job. }\end{array}$ & 29 & 0 & .00 & 11 & 37.93 & 11 & 37.93 & 5 & 17.24 & 2 & 6.90 \\
\hline Lesson preparation & 28 & 0 & .00 & 10 & 35.71 & 14 & 50.00 & 3 & 10.71 & 1 & 3.57 \\
\hline
\end{tabular}


Table 4 (continued)

Significance of the Problems Student Teachers Encountered

\begin{tabular}{|c|c|c|c|c|c|c|c|c|c|c|c|}
\hline \multirow[b]{2}{*}{ Problems } & \multirow[b]{2}{*}{$n$} & \multicolumn{2}{|c|}{ N/A } & \multicolumn{2}{|c|}{ Not a Problem } & \multicolumn{2}{|c|}{ Minor Problem } & \multicolumn{2}{|c|}{$\begin{array}{l}\text { Moderate } \\
\text { Problem }\end{array}$} & \multicolumn{2}{|c|}{ Serious Problem } \\
\hline & & $f$ & $\%$ & $f$ & $\%$ & $f$ & $\%$ & $f$ & $\%$ & $f$ & $\%$ \\
\hline $\begin{array}{l}\text { Ability to keep up WVU } \\
\text { level lesson plans. }\end{array}$ & 28 & 0 & .00 & 11 & 39.29 & 9 & 32.14 & 7 & 25.00 & 1 & 3.57 \\
\hline $\begin{array}{l}\text { Ability to keep students } \\
\text { engaged }\end{array}$ & 29 & 0 & .00 & 7 & 24.14 & 19 & 65.52 & 3 & 10.34 & 0 & .00 \\
\hline $\begin{array}{l}\text { Ability to teach students } \\
\text { with different skill levels }\end{array}$ & 29 & 0 & .00 & 5 & 17.24 & 19 & 65.52 & 3 & 10.34 & 2 & 6.90 \\
\hline $\begin{array}{l}\text { Ability to differentiate } \\
\text { instruction }\end{array}$ & 29 & 0 & .00 & 9 & 31.03 & 15 & 51.72 & 3 & 10.34 & 2 & 6.90 \\
\hline $\begin{array}{l}\text { Lack of record book } \\
\text { knowledge }\end{array}$ & 29 & 1 & 3.45 & 6 & 20.69 & 14 & 48.28 & 5 & 17.24 & 3 & 10.34 \\
\hline $\begin{array}{l}\text { Lack of knowledge in } \\
\text { agricultural mechanics }\end{array}$ & 29 & 2 & 6.90 & 5 & 17.24 & 13 & 44.83 & 4 & 13.79 & 5 & 17.24 \\
\hline
\end{tabular}


The population was then asked how frequently they encountered the problem of their student teachers ability to handle students who did not want to be in class. Of the respondents $3.85 \%(f=1)$ found the frequency to be not applicable, $15.38 \%(f=4)$ rated it as never a problem, $73.08 \%(f=19)$ considered it to occur occasionally/sometimes, 7.69\% $(f=2)$ reported it happened almost every time, and none of the respondents considered it to occur every time. When asked about the student teachers time management $7.69 \%(f=2)$ of the respondents perceived it to be not applicable, however 19.23\% $(f=5)$ said it was never a problem, 53.85\% $(f=14)$ rated it as occasionally/sometimes a problem, $19.23 \%(f=5)$ considered it to occur almost every time, and zero reported it to be every time. Two (8\%) of the respondents perceived the problem of their student teachers total time commitment to the job to be non-applicable. However, 32\% $(f=8)$ reported it was never a problem, $52 \%(f=13)$ considered it to occur occasionally/sometimes, $8 \%(f=2)$ identified it happening almost every time, and zero respondents rated it occurring every time.

Next was the problem about student teachers lesson preparation, 3.85\% $(f=1)$ of the respondents found it to be not applicable, while $30.77 \%(f=8)$ said it was never a problem, 38.46\% $(f=10)$ rated it as an occasionally/sometimes occurring problem, 19.23\% $(f=5)$ said almost every time, and 7.69\% $(f=2)$ perceived it to occurred every time. Ability to keep up with WVU level lesson plans was rated by zero respondents as not applicable, 28\% $(f=7)$ reported it was never a problem or that it occurred almost every time, $40 \%(f=10)$ said it was occasionally/sometimes, while $4 \%(f=1)$ considered it to be a problem that occurred every time. Student teachers ability to keep students engaged was considered not applicable by zero respondents, but $16 \%(f=4)$ said it was 
never a problem, 72\% $(f=18)$ occasionally/sometimes, $12 \%(f=3)$ almost every time, and none considered it to happen every time.

Cooperating teachers were then asked about the frequency of their student teachers ability to teach students with different skill levels. Of the respondents $3.85 \%$ ( $f=$ 1) perceived it to be not applicable, $15.38 \%(f=4)$ said never, $73.08 \%(f=19)$ occasionally/sometimes, 7.69\% ( $\mathrm{f}=2$ ) almost every time, and zero found it occurring every time. Student teachers ability to differentiate instruction was considered not applicable to $4.17 \%(f=1)$ of respondents, while $25 \%(f=6)$ said it was never a problem, 62.5\% $(f=15)$ occasionally/sometimes, 8.33\% $(f=2)$ identified almost every time with zero respondents reporting it occur every time. Student teachers lack of record book knowledge was considered not applicable by none of the respondents, while $20.83 \%$ ( $f=$ 5) identified it was never a problem, $62.5 \%(f=15)$ said occasionally/sometimes, $12.5 \%$ $(f=3)$ found it to be almost every time, and $4.17 \%(f=1)$ saw it occurring every time. The last question related to the student teachers, asked about the frequency of their lack of knowledge in agricultural mechanics. Of the respondents, $8 \%(f=2)$ rated it as not applicable, 20\% $(f=5)$ found it to never be a problem, $40 \%(f=10)$ saw it occasionally/sometimes, while 20\% $(f=5)$ said it occurred almost every time, and $12 \%(f$ = 3) perceived it to occur every time. 
Table 5

Frequency of the Problems Student Teachers Encountered

\begin{tabular}{|c|c|c|c|c|c|c|c|c|c|c|c|}
\hline \multirow[b]{2}{*}{ Problem } & \multirow[b]{2}{*}{$n$} & \multicolumn{2}{|c|}{ N/A } & \multicolumn{2}{|c|}{ Never } & \multicolumn{2}{|c|}{$\begin{array}{l}\text { Occasionally/ } \\
\text { Sometimes }\end{array}$} & \multicolumn{2}{|c|}{$\begin{array}{l}\text { Almost Every } \\
\text { time }\end{array}$} & \multicolumn{2}{|c|}{ Every time } \\
\hline & & $f$ & $\%$ & $f$ & $\%$ & $f$ & $\%$ & $f$ & $\%$ & $f$ & $\%$ \\
\hline Classroom management & 27 & 0 & .00 & 4 & 14.81 & 19 & 70.37 & 3 & 11.11 & 1 & 3.70 \\
\hline $\begin{array}{l}\text { Knowing how to handle } \\
\text { discipline problems when } \\
\text { they arise }\end{array}$ & 26 & 0 & .00 & 2 & 7.69 & 21 & 80.77 & 2 & 7.69 & 1 & 3.85 \\
\hline $\begin{array}{l}\text { Not having a strong } \\
\text { discipline plan in place }\end{array}$ & 25 & 0 & .00 & 2 & 8.00 & 18 & 72.00 & 3 & 12.00 & 2 & 8.00 \\
\hline $\begin{array}{l}\text { Not being prepared to } \\
\text { handle secondary students } \\
\text { who did not want to be in } \\
\text { the class }\end{array}$ & 26 & 1 & 3.85 & 4 & 15.38 & 19 & 73.08 & 2 & 7.69 & 0 & .00 \\
\hline Time management & 26 & 2 & 7.69 & 5 & 19.23 & 14 & 53.85 & 5 & 19.23 & 0 & .00 \\
\hline $\begin{array}{l}\text { Total time commitment to } \\
\text { the job. }\end{array}$ & 25 & 2 & 8.00 & 8 & 32.00 & 13 & 52.00 & 2 & 8.00 & 0 & .00 \\
\hline Lesson preparation & 26 & 1 & 3.85 & 8 & 30.77 & 10 & 38.46 & 5 & 19.23 & 2 & 7.69 \\
\hline
\end{tabular}


Table 5 (continued)

Frequency of the Problems Student Teachers Encountered

\begin{tabular}{|c|c|c|c|c|c|c|c|c|c|c|c|}
\hline \multirow[b]{2}{*}{ Problem } & \multirow[b]{2}{*}{$n$} & \multicolumn{2}{|c|}{ N/A } & \multicolumn{2}{|c|}{ Never } & \multicolumn{2}{|c|}{$\begin{array}{l}\text { Occasionally/ } \\
\text { Sometimes }\end{array}$} & \multicolumn{2}{|c|}{$\begin{array}{l}\text { Almost Every } \\
\text { time }\end{array}$} & \multicolumn{2}{|c|}{ Every time } \\
\hline & & $f$ & $\%$ & $f$ & $\%$ & $f$ & $\%$ & $f$ & $\%$ & $f$ & $\%$ \\
\hline $\begin{array}{l}\text { Ability to keep up WVU } \\
\text { level lesson plans. }\end{array}$ & 25 & 0 & .00 & 7 & 28.00 & 10 & 40.00 & 7 & 28.00 & 1 & 4.00 \\
\hline $\begin{array}{l}\text { Ability to keep students } \\
\text { engaged }\end{array}$ & 25 & 0 & .00 & 4 & 16.00 & 18 & 72.00 & 3 & 12.00 & 0 & .00 \\
\hline $\begin{array}{l}\text { Ability to teach students } \\
\text { with different skill levels }\end{array}$ & 26 & 1 & 3.85 & 4 & 15.38 & 19 & 73.08 & 2 & 7.69 & 0 & .00 \\
\hline $\begin{array}{l}\text { Ability to differentiate } \\
\text { instruction }\end{array}$ & 24 & 1 & 4.17 & 6 & 25.00 & 15 & 62.50 & 2 & 8.33 & 0 & .00 \\
\hline $\begin{array}{l}\text { Lack of record book } \\
\text { knowledge }\end{array}$ & 24 & 0 & .00 & 5 & 20.83 & 15 & 62.50 & 3 & 12.50 & 1 & 4.17 \\
\hline $\begin{array}{l}\text { Lack of knowledge in } \\
\text { agricultural mechanics }\end{array}$ & 25 & 2 & 8.00 & 5 & 20.00 & 10 & 40.00 & 5 & 20.00 & 3 & 12.00 \\
\hline
\end{tabular}




\section{Student Teachers Knowledge Proficiency in Content Areas}

The second section of the survey strived to identify the proficiency of the student teachers content knowledge. The population was asked to reply with an average proficiency based on the student teachers they have supervised (see Table 6). In the area of agricultural mechanics, $7.41 \%(f=2)$ of respondents said it was not applicable, $18.52 \%(f=5)$ perceived them as not proficient, $44.44 \%(f=12)$ somewhat proficient, 22.22\% $(f=6)$ moderately proficient, and 7.41\% $(f=2)$ responded with extremely proficient. Agricultural business proficiency was found to be not applicable by $7.14 \%$ ( $f=$ 2) of respondents, zero for not proficient, $46.43 \%(f=13)$ somewhat proficient, $35.71 \%(f$ $=10)$ moderately proficient, and $10.71 \%(f=3)$ extremely proficient.

Two (7.14\%) respondents found the proficiency of student teachers knowledge in FFA/SAE to be not applicable or not proficient, while $32.14 \%(f=9)$ somewhat proficient, 25\% ( $f=7)$ moderately proficient, and 28.57\% $(f=8)$ said extremely proficient. Student teachers proficiency in food/meat science was identified by $33.33 \%$ ( $f$ = 9) of respondents as not applicable, 18.52\% $(f=5)$ said not proficient, $29.63 \%(f=8)$ somewhat proficient, $18.52 \%(f=5)$ moderately proficient, and zero respondents considered student teachers to be extremely proficient. In the content area of large animal science $11.11 \%(f=3)$ of cooperating teachers rated content knowledge as not applicable, while zero chose not proficient, 33.33\% $(f=9)$ somewhat proficient, $44.44 \%(f=12)$ moderately proficient and $11.11 \%(f=3)$ responded with extremely proficient. Small animal science yielded 37.04\% $(f=10)$ respondents for not applicable, 3.70\% $(f=1)$ not proficient, 37.04\% $(f=10)$ somewhat proficient, $22.22 \%(f=6)$ moderately proficient, and zero respondents believed their student teachers to be extremely proficient. 
Student teachers content knowledge in forestry was found not applicable by 28.57\% ( $(=8)$ respondents, not proficient by $14.29 \%(f=4)$, somewhat proficient by 42.86\% ( $f=12)$, moderately proficient and extremely proficient by $7.14 \%(f=2)$ respondents for each category. Four (14.29\%) respondents noted not applicable in the content area of natural resources while 7.14\% $(f=2)$ said not proficient, $46.43 \%(f=13)$ somewhat proficient, $28.57 \%(f=8)$ moderately proficient, and only one (3.57\%) stating extremely proficient.

The plant science content area yielded not applicable by $10.71 \%(f=3)$ of respondents with 7.14\% $(f=2)$ not proficient, 39.29\% $(f=11)$ somewhat proficient, 42.86\% ( $f=12)$ moderately proficient, and zero respondents perceiving their students teachers to be extremely proficient. In the content area of soil science, $14.29 \%(f=4)$ of respondents rated them as not applicable, 7.14\% $(f=2)$ not proficient, 50\% $(f=14)$ somewhat proficient, 25\% ( $f=7)$ moderately proficient, and 3.57\% $(f=1)$ responded with extremely proficient. The final content area was greenhouse management with five (17.86\%) of respondents rating it as not applicable, $14.29 \%(f=4)$ responded with not proficient, $50 \%(f=14)$ somewhat proficient, $17.86 \%(f=5)$ moderately proficient, and zero respondents perceiving their student teachers to be extremely proficient. 
Table 6

Student Teacher's Perceived Knowledge Proficiency in Content Areas

\begin{tabular}{|c|c|c|c|c|c|c|c|c|c|c|c|}
\hline \multirow[b]{2}{*}{ Content Area } & \multirow[b]{2}{*}{$n$} & \multicolumn{2}{|c|}{ Not Applicable } & \multicolumn{2}{|c|}{ Not Proficient } & \multicolumn{2}{|c|}{$\begin{array}{l}\text { Somewhat } \\
\text { Proficient }\end{array}$} & \multicolumn{2}{|c|}{$\begin{array}{c}\text { Moderately } \\
\text { Proficient }\end{array}$} & \multicolumn{2}{|c|}{$\begin{array}{l}\text { Extremely } \\
\text { Proficient }\end{array}$} \\
\hline & & $f$ & $\%$ & $f$ & $\%$ & $f$ & $\%$ & $f$ & $\%$ & $f$ & $\%$ \\
\hline Agricultural Mechanics & 27 & 2 & 7.41 & 5 & 18.52 & 12 & 44.44 & 6 & 22.22 & 2 & 7.41 \\
\hline Agricultural Business & 28 & 2 & 7.14 & 0 & .00 & 13 & 46.43 & 10 & 35.71 & 3 & 10.71 \\
\hline FFA/SAE & 28 & 2 & 7.14 & 2 & 7.14 & 9 & 32.14 & 7 & 25.00 & 8 & 28.57 \\
\hline Food/Meat Science & 27 & 9 & 33.33 & 5 & 18.52 & 8 & 29.63 & 5 & 18.52 & 0 & .00 \\
\hline Large Animal Science & 27 & 3 & 11.11 & 0 & .00 & 9 & 33.33 & 12 & 44.44 & 3 & 11.11 \\
\hline Small Animal Science & 27 & 10 & 37.04 & 1 & 3.70 & 10 & 37.04 & 6 & 22.22 & 0 & .00 \\
\hline Forestry & 28 & 8 & 28.57 & 4 & 14.29 & 12 & 42.86 & 2 & 7.14 & 2 & 7.14 \\
\hline Natural Resources & 28 & 4 & 14.29 & 2 & 7.14 & 13 & 46.43 & 8 & 28.57 & 1 & 3.57 \\
\hline Plant Science & 28 & 3 & 10.71 & 2 & 7.14 & 11 & 39.29 & 12 & 42.86 & 0 & .00 \\
\hline Soil Science & 28 & 4 & 14.29 & 2 & 7.14 & 14 & 50.00 & 7 & 25.00 & 1 & 3.57 \\
\hline Greenhouse Management & 28 & 5 & 17.86 & 4 & 14.29 & 14 & 50.00 & 5 & 17.86 & 0 & .00 \\
\hline
\end{tabular}




\section{Significance of Cooperating Teacher Challenges}

Once the cooperating teachers identified the significance and frequency of the problems they perceived in their student teachers, they were asked to identify both in the challenges they found themselves encountering. Cooperating teachers were asked to rate the significance on the following problems they encountered as they supervised a student teachers (see Table 7).

Cooperating teachers stated that being able to secure materials due to lack of advance pre-planning of their student teacher was a problem. Zero respondents found this to be not applicable, $42.86 \%(f=12)$ said it was not a problem, with the same amount saying it was a minor problem. Three $(10.71 \%)$ of respondents perceived it to be a moderate problem with $3.57 \%(f=1)$ considering it a serious problem. When asked about the significance of having a student teacher who did not understand the time commitment that comes with being an agricultural instructor none of the respondents considered it to be not applicable, $42.86 \%(f=12)$ not a problem, 35.71\% $(f=10)$ minor problem, 17.86\% $(f=5)$ moderate problem, and 3.57\% $(f=1)$ said it was a serious problem. The final problem cooperating teachers faced was their student teachers understanding of the time commitment needed to run the total program. The significance of the problem yielded 3.57\% $(f=1)$ not applicable, 35.71\% $(f=10)$ not a problem, $28.57 \%(f=8)$ minor problem, with the same amount for moderate problem, and 3.57\% $(f=1)$ respondents who perceived it to be a serious problem. 
Table 7

Significance of Problems Cooperating Teachers Encountered

\begin{tabular}{|c|c|c|c|c|c|c|c|c|c|c|}
\hline \multirow[b]{2}{*}{ Problems } & \multicolumn{2}{|c|}{ N/A } & \multicolumn{2}{|c|}{ Not a Problem } & \multicolumn{2}{|c|}{ Minor Problem } & \multicolumn{2}{|c|}{ Moderate Problem } & \multicolumn{2}{|c|}{ Serious Problem } \\
\hline & $f$ & $\%$ & $f$ & $\%$ & $f$ & $\%$ & $f$ & $\%$ & $f$ & $\%$ \\
\hline $\begin{array}{l}\text { Being able to secure materials } \\
\text { due to lack of advance pre- } \\
\text { planning of pre-service } \\
\text { teacher(s) }\end{array}$ & 0 & .00 & 12 & 42.86 & 12 & 42.86 & 3 & 10.71 & 1 & 3.57 \\
\hline $\begin{array}{l}\text { Having a pre-service teacher } \\
\text { who did not understand the } \\
\text { time commitment that comes } \\
\text { with being an agricultural } \\
\text { instructor }\end{array}$ & 0 & .00 & 12 & 42.86 & 10 & 35.71 & 5 & 17.86 & 1 & 3.57 \\
\hline $\begin{array}{l}\text { My pre-service teacher(s) } \\
\text { understanding of the time } \\
\text { commitment needed to run the } \\
\text { total program }\end{array}$ & 1 & 3.57 & 10 & 35.71 & 8 & 28.57 & 8 & 28.57 & 1 & 3.57 \\
\hline
\end{tabular}


Cooperating teachers were asked to rate the frequency of the problems they encountered with student teachers (see Table 8). The frequency of the issue of being able to secure materials due to lack of advance pre-planning of their student teacher yielded 8.33\% $(f=2)$ respondents that considered it not applicable, 33.33\% $(f=8)$ never, $45.83 \%$ $(f=11)$ occasionally/sometimes, $12.5 \%(f=3)$ almost every time, and zero respondents perceiving it to occur every time. The frequency of having a student teacher who did not understand the time commitment that comes with being an agricultural instructor found 4.35\% $(f=1)$ responding not applicable, 17.39\% $(f=4)$ never, 60.87\% $(f=14)$ occasionally/sometimes, 13.04\% $(f=3)$ almost every time, and 4.35\% $(f=1)$ responded with every time. The final problem cooperating teachers faced was their student teachers understanding of the time commitment needed to run the total program. The frequency of the problem yielded 4.35\% $(f=1)$ not applicable, 13.04\% $(f=3)$ never, $73.91 \%(f=17)$ occasionally/sometimes, $8.70 \%(f=2)$ almost every time, and zero respondents who encountered it every time. . 
Table 8

Frequency of the Problems Cooperating Teachers Encountered

\begin{tabular}{|c|c|c|c|c|c|c|c|c|c|c|c|}
\hline \multirow[b]{2}{*}{ Problems } & \multirow[b]{2}{*}{$n$} & \multicolumn{2}{|c|}{ N/A } & \multicolumn{2}{|c|}{ Never } & \multicolumn{2}{|c|}{$\begin{array}{l}\text { Occasionally/ } \\
\text { Sometimes }\end{array}$} & \multicolumn{2}{|c|}{$\begin{array}{l}\text { Almost Every } \\
\text { time }\end{array}$} & \multicolumn{2}{|c|}{ Every time } \\
\hline & & $F$ & $\%$ & $f$ & $\%$ & $f$ & $\%$ & $f$ & $\%$ & $f$ & $\%$ \\
\hline $\begin{array}{l}\text { Being able to secure materials } \\
\text { due to lack of advance pre- } \\
\text { planning of pre-service } \\
\text { teacher(s) }\end{array}$ & 24 & 2 & 8.33 & 8 & 33.33 & 11 & 45.83 & 3 & 12.50 & 0 & .00 \\
\hline $\begin{array}{l}\text { Having a pre-service teacher } \\
\text { who did not understand the } \\
\text { time commitment that comes } \\
\text { with being an agricultural } \\
\text { instructor }\end{array}$ & 23 & 1 & 4.35 & 4 & 17.39 & 14 & 60.87 & 3 & 13.04 & 1 & 4.35 \\
\hline $\begin{array}{l}\text { My pre-service teacher(s) } \\
\text { understanding of the time } \\
\text { commitment needed to run the } \\
\text { total program }\end{array}$ & 23 & 1 & 4.35 & 3 & 13.04 & 17 & 73.91 & 2 & 8.70 & 0 & .00 \\
\hline
\end{tabular}




\section{CHAPTER V}

\section{Summary, Conclusions, and Recommendations}

\section{Purpose of the Study}

The purpose of this study was to identify the challenges secondary agricultural cooperating teachers perceived their student teachers to face, the significance of those challenges, and the frequency in which they occurred. This study also set out to identify the challenges that the cooperating teachers perceived themselves to encounter when supervising a student teacher, the significance of those challenges and the frequency in which they occurred. Data will allow the challenges to be identified and shared with teacher educators, state supervisors, and department faculty to better prepare student teachers and cooperating teachers.

\section{Objectives}

The objectives of this study were to identify what cooperating teachers perceive to be challenges when supervising a secondary Agricultural education student teacher from WVU.

The following questions provided direction for the study:

1. What did cooperating teachers perceive to be significant challenges for the student teachers they have supervised from West Virginia University’s Agricultural and Extension Education department between 2006-2016?

2. What did cooperating teachers perceive to be significant challenges they faced while supervising a student teacher from West Virginia University’s Agricultural and Extension Education department between 2006-2016? 
3. How frequently have these challenges occurred with student teachers they have supervised between 2006-2016?

\section{Summary of Findings}

The population consisted of secondary agricultural educators who have served as cooperating teachers for West Virginia University’s Agricultural and Extension Education department. Individuals were limited to those who have been cooperating teachers within the past five years, 2011-2016. The total population was comprised of 53 individuals. The final response rate received for the study was over half (55\%) of the population.

The respondents were identified through demographical information from questions asked. Over half of the respondents were male with a majority in the age range of 50 years or older. More than half of the respondents identified a Master's as their highest obtained degree. A majority of the individuals who responded have at least 20 years of experience teaching. Respondents had anywhere from 50 to 250 students in their agricultural program and ranged from one to four teachers in their department. The cooperating teachers who responded also have supervised anywhere between 1 to 12 student teachers over the past 10 years.

\section{Challenges Cooperating Teachers Observed in Student Teachers}

Throughout the study, the respondents identified many challenges they observed their pre-service teachers facing during the student teaching experience. Some of the identified challenges matched those identified by Fritz \& Mantooth (2005). These included time management, discipline/classroom management, and lack of knowledge in content areas. The final phase identified thirteen of those challenges and looked at the 
significance and frequency of each. The majority of respondents perceived the significance of all of the stated problems to be minor. Results showed anywhere from a majority to more than half of respondents rating them. The frequency of the thirteen problems fell into the occasionally/sometimes category a majority of the time.

\section{Content Knowledge of Student Teachers}

The population was asked to identify an average knowledge proficiency for their student teachers in eleven content areas. Agricultural mechanics, agricultural business, and FFA/SAE all yielded a majority response of student teachers being on average somewhat proficient in content knowledge. Food/meat science had a majority of respondents considering the content area to not apply to their program, however where it did apply, that majority said on average they felt their student teachers were somewhat proficient. Large animal science yielded a moderately proficient rating according to the majority of respondents and small animal science had a tie between not applicable and somewhat proficient. In both the forestry and natural resources content areas, a majority of respondents identified the knowledge average to be somewhat proficient. Student teachers were found on average to be moderately proficient in plant science by a majority of respondents. The final two content areas, soil science and greenhouse management yielded a somewhat proficient rating with exactly half of all respondents reporting it.

\section{Challenges Cooperating Teachers Faced Supervising a Student Teacher}

Phase I provided several challenges that cooperating teachers identified themselves encountering. Some were similar but did not fully match up to those found by Paulson (2014) when conducting a study on the challenges that cooperating teacher face. The result from Phase II provided the final phase with only three challenges that $52 \%$ of 
respondents agreed to encountering. The significance of the first challenge, being able to secure materials due to lack of advance pre-planning of student teachers was a tie between not a problem and a minor problem, yielding the exact same number of responses. A majority of respondents identified the frequency of this problem as occasionally/sometimes. The challenge of having student teachers who did not understand the time commitment that comes with being an agricultural instructor was perceive as not a problem according to a majority of respondents. The frequency of the problem was perceived as occasionally/sometimes with over half of respondents. The final challenge that cooperating teachers faced was their student teachers understanding of the time commitment needed to run the total program. A majority of respondents considered this not a problem and over half said it occurred occasionally/sometimes.

\section{Conclusions}

Based on the results of this study, the following conclusions can be made:

1. The results support that of Fritz and Mantooth (2005). Cooperating teachers identified time management, classroom management/discipline, and lack of knowledge in specific content areas to be challenges that student teachers faced. These challenges surfaced in this study as well.

2. Cooperating teachers identified more challenges they observed their student teachers facing than challenges they faced as a cooperating teacher.

3. A majority of the challenges faced by the student teachers were considered minor problems and only occur occasionally/sometimes.

4. On average student teachers were considered somewhat proficient in the eleven agricultural content areas. 
5. Cooperating teachers considered their challenges to not be significant and reported them occurring occasionally/sometimes.

\section{Recommendations}

The researcher makes the following recommendations based on the results of the study:

\section{Student Teachers}

1. Upcoming student teachers should be encouraged to take classes outside of the required courses in order to build a strong content knowledge basis.

2. Discuss with your cooperating teacher the specifics of the program you will be instructing, this will help you be prepared for the time commitment needed during the student teacher experience.

3. Be prepared to handle discipline problems and be prepared everyday utilizing your time wisely.

\section{Cooperating Teachers}

1. Express to an incoming student teacher the time commitment associated with your program.

2. Discuss with your student teacher lessons they plan on teaching at the beginning of the experience in order to secure supplies needed for lessons.

3. Set aside time daily to provide your student teacher with feedback in order to eliminate challenges or problems from happening in the future.

\section{Further Studies}

1. A study should be conducted to identify what student teachers feel are challenges they encountered during the student teaching experience. 
2. A study should be conducted to identify what university supervisors observe as challenges that cooperating teachers experience while hosting student teachers.

3. A qualitative study should be conducted, interviewing cooperating teachers to see if they are more open to identifying challenges they encountered.

4. A study should be conducted to identify what first year cooperating teachers feel are challenges they encountered. 


\section{REFERENCES}

Ary, D., Jacobs, L. C., Sorensen, C. K., \& Walker, D. A. (2014). Introduction to research in education (9th ed.). Belmont, CA: Wadsworth.

Atherton, J. D. (1950). Conference with supervising teachers. Agricultural Education Magazine, 23(4), 95.

Bacharach, N. L., Heck, T. W., \& Dahlberg, K. (2010). Changing the face of student teaching through co-teaching. Retrieved from http://repository.stcloudstate.edu/ed_facpubs/1

Baum, A. C., \& Korth, B. B. (2013). Preparing classroom teachers to be cooperating teachers: A report of current efforts, beliefs, challenges, and associated recommendations. Journal of Early Childhood Teacher Education, 34(2), 171190. DOI: http://dx.doi.org/10.1080/10901027.2013.787478

Bird, L. K. (2012). Student teacher perceptions on the impact of mentoring on student teaching. Retrieved from http://www.search.proquest.com/docview/10234466849?pq-origsite=summon

Bradley, H. R. (1974). A seminar for cooperating teachers in Kansas. Agricultural Education Magazine, 47(3), 69.

Cardozier, V. R., (Ed.) (1967). Teacher education in agriculture. Danville, IL: The Interstate Printers \& Publishers, Inc.

DeMoulin, D. F. (1993). Efficacy and educational effectiveness. In J. R. Hoyle \& D. M. Estes (Eds.), NCPEA: In a new voice (p. 155-167). Lancaster, PA: Technomic Publishing Company, Inc. 
Dillman, D. A., Smyth, J. D., \& Christian, L. M. (2009). Internet, mail \& mixed-mode Surveys: The tailored design method ( ${ }^{\text {rd }}$ ed.). Hoboken, NJ: John Wiley \& Sons Inc.

Edwards, S. W. (2012). The effects of the student teaching experience on cooperating teachers in secondary agricultural education programs: A case study. Retrieved http://www.search.proquest.com.www.libproxy.wvu.edu

Fritz, C. A., \& Mantooth, L., J. (2005). Challenges expressed by cooperating teacher mentors when working with agricultural education student teachers: A delphi study. NACTA Journal, 49(4), 51-56.

Kasperbauer, H., \& Roberts, G. (2007). Influence of the relationship between the student teacher and cooperating teacher on student teacher's decision to enter teaching. Journal of Agricultural Education, 48(1) 8-19. DOI: 10.5032/jae.2007.01008

Khuns, G. (1972). So you're a cooperating teacher. Agricultural Education Magazine, 45(2), 41.

Linstone, H. A., \& Turoff, M. (1975). Introduction. In H. A. Linstone \& M. Turoff (Eds.). The Delphi method: Techniques and applications. Reading: MA AddisonWesley Publishing Company

McGuire, V., Myers, R., \& Durrance, C. (1959). Your student teaching in the secondary school. (1 ${ }^{\text {st }}$ ed.). Boston: Allyn and Bacon. Retrieved from https://babel.hathitrust.org/cgi/pt?id=mdp.39015070543866;view=1up;seq=7

Mecca, J. A. (2010) Case study of supervising a student teacher: Its impact on the cooperating teacher's professional development. Retrieved from http://www.search.proquest.com/docview/816838064?pq-origsite=summon 
Mezirow, J. (1997). Transformative learning: Theory to practice. New Directions for Adult and Continuing Education 1997(74), 5-12. Retrieved from: ad4tq3gq5x.search.serialsolutions.com

Mezirow, J. (2000). Learning as transformation. ( $1^{\text {st }}$ ed.). San Francisco: Jossey-Bass Inc.

Miller, L. E., \& Smith, K. L. (1983). Handling nonresponse issues. Journal of Extension, 21(5), 45-50.

National FFA. (2016). Official FFA manual. Retrieved from https://www.ffa.org/about/who-we-are/official-manual

Norris, R. J., Larke, A. Jr., \& Briers, G. E. (1990). Selection of student teaching centers and cooperating teachers in agriculture and expectations of teacher educators regarding these components of a teacher education program: a national study. Journal of Agricultural Education, 31(1), 58-63. DOI: 10.5032/jae.1990.01058

Oregon State University. (2016). Agricultural education handbook: Teacher licensure program handbook. Retrieved from http://blogs.oregonstate.edu/agriculturehandbook/responsibilities-of-the-studentteacher/

Paulson, D. (2014). Perceptions of cooperating teachers concerning the student teaching field experience. Retrieved from http://www.search.proquest.com.www.libproxy.wvu.edu

Purdue University. (2013). Cooperating teacher handbook: Purdue University Agricultural Education. Retrieved from www.ydea.purdue.edu/downloads/undergrad/pdf 
Robinson, J. P., Shaver, P. R., \& Wrightsman, L. S. (1991). Measures of personality and social psychological attitudes. (Vol 1). New York:Academic Pr.

Schumann, H. (1969). The cooperating teacher's role in student teaching. Agricultural Education Magazine, 41(7), 156.

Shoulders, C. W., \& Myers, B. D. (2012). Teacher's use of agricultural laboratories in secondary agricultural education. Journal of Agricultural Education, 53(2) 124138. DOI: $10.5032 /$ jae.2010.02124

Smalley, S., Retallick, M., \& Paulsen, T. (2015). Relevance of student teaching skills and activities from the perspective of the student teacher. Journal of Agricultural Education, 56(1), 73-91. DOI: 10.5032/jae.2015.01073

Talbert, A. B., Vaughn, R., Croom, D. B., \& Lee, J. S. (2007). Foundations of agricultural education. (2 ${ }^{\text {nd }}$ ed.). Danville, IL: Professional Educators Publications, Inc.

West Virginia Department of Education. (2015). Professional educator preparation requirements: Teacher. (Policy 5100 §123-114-6 6.4.b3). Charleston, WV: Secretary of State

West Virginia University. (n.d.) WVU: Student teacher handbook.

Young, R. B., \& Edwards, M. C. (2006). Important elements of the student teaching experience in agricultural education: A comparison of cooperating teachers’ and student teachers’ perceptions. Journal of Southern Agricultural Education Research, 56(1), 89-100. 
APPENDIX A

Phase I Survey 


\section{CHALLENGES PERCEIVED BY COOPERATING TEACHERS WHILE SUPERVISING STUDENT TEACHERS}

Please list up to 3 significant challenges you have observed pre-service teachers facing during the student teacher experience. When considering these challenges please focus on student teachers you have supervised from West Virginia University's Agricultural and Extension Education department between 2006-2016.

1.

2.

3.

Please list up to 3 significant challenges you have encountered while supervising a preservice teacher from West Virginia University's Agricultural Education and Extension department. When considering these challenges please focus on the student teachers you supervised between 2006-2016.

1.

2.

3.

If you would prefer to receive the next phase of the study electronically, please provide your email. If not, we will send you a paper copy in the mail.

Email:

Please return this form in the enclosed return envelope by March 29, 2017. Thank you for your participation. 
APPENDIX B

Cover Letter 
February 13, 2017

\section{Dear Cooperating Teacher:}

I would like to send a sincere thank you for serving as a cooperating teacher for the West Virginia University Agricultural Extension Education program. It is individuals like you who have helped others as well as me pursue our dreams of becoming future educators. We truly could not have done it without you.

I am Samantha Cogle, a graduate student in Agricultural and Extension Education. Under the direction of my advisor, Dr. Stacy Gartin, we are conducting a study to determine the challenges that cooperating teachers encounter when supervising a student teacher. The results of this study will be used to prepare a thesis to partially fulfill the requirements of a Master of Science in Agricultural and Extension Education. We are contacting agricultural educators who have served as cooperating teachers for West Virginia University's agricultural education pre-service teachers between the years 2011 and 2016. The results will provide information to teacher educators in order to help better manage the student teacher experience.

Participation in this research study is completely voluntary and all information you provide will be held as confidential as possible. This study will be conducted in three phases with this being the first. This survey should only take about 8 minutes. Your response is crucial to the success of the study. You may skip the question if you are not comfortable answering and you may stop at any time. Survey results will be reported in a summary format and individual responses will not be identifiable.

The Institutional Review Board (IRB) at West Virginia University has approved this study (IRB \#). If you have any questions or concerns about completing the questionnaire or about participating in this study, you may contact me at scogle@mix.wvu.edu or (304)641-5548.

Please place the completed survey in the enclosed postage-paid self-addressed return envelope and place it in the mail. Please return your completed survey before February 20, 2017. Thank you in advance for your assistance with this study, we sincerely appreciate your participation.

Respectfully yours,

Samantha L. Cogle Graduate Student

Agricultural and Extension Education Education
Stacy A. Gartin, Ph.D.

Professor

Agricultural and Extension 
APPENDIX C

Follow-up Letter 
February 23, 2017

Dear Cooperating Teacher:

A few weeks ago we sent you a mailing about an important research study we are conducting. The purpose of this study is to identify the challenges that you, as a cooperating teacher, faced while supervising a student teacher. Unless your response is in the mail, we have not heard from you. In order to assure the results, represent the views of all who have served as cooperating teachers for the WVU Agricultural and Extension Education program, your feedback is important. I would like to send a sincere thank you for serving as a cooperating teacher for the West Virginia University Agricultural Extension Education program. It is individuals like you who have helped others as well as me pursue our dreams of becoming future educators. We truly could not have done it without you.

I am Samantha Cogle, a graduate student in Agricultural and Extension Education. Under the direction of my advisor, Dr. Stacy Gartin, we are conducting a study to determine the challenges that cooperating teachers encounter when supervising a student teacher. The results of this study will be used to prepare a thesis to partially fulfill the requirements of a Master of Science in Agricultural and Extension Education. We are contacting agricultural educators who have served as cooperating teachers for West Virginia University’s agricultural education pre-service teachers between the years 2011 and 2016. The results will provide information to teacher educators in order to help better manage the student teacher experience.

Participation in this research study is completely voluntary and all information you provide will be held as confidential as possible. This study will be conducted in three phases with this being the first. This survey should only take about 8 minutes. Your response is crucial to the success of the study. You may skip the question if you are not comfortable answering and you may stop at any time. Survey results will be reported in a summary format and individual responses will not be identifiable.

The Institutional Review Board (IRB) at West Virginia University has approved this study Protocol \#1702458725. If you have any questions or concerns about completing the questionnaire or about participating in this study, you may contact me at scogle@mix.wvu.edu or (304)641-5548.

Please place the completed survey in the enclosed postage-paid self-addressed return envelope and place it in the mail. Please return your completed survey before March 10, 2017. Thank you in advance for your assistance with this study, we sincerely appreciate your participation.

Respectfully yours,

Samantha L. Cogle

Graduate Student

Agricultural and Extension Education Education
Stacy A. Gartin, Ph.D.

Professor

Agricultural and Extension 
APPENDIX D

Phase I Results 
Challenges Pre-Service Teachers Faced

Being prepared fro class. Time Management was a challenge for one of the student teachers I worked with

Time

Time Management

Time Management

Time Management

Time Management Skills

Time Management Skills

Time Management-Especially with block schedule

Time Management-Getting activities done during certain amounts of time or allotted

Understanding how to planto cover time alloted to teach. Its hard to move from 20 mins practice in methods to $50 \mathrm{~min}$ or more in reality.

Pacing/timing of lessons-Modifying plans if needed from time

Lacking the understanding of the amount of timeit takes to be prepared for a full day of teaching.

Time Management

Classroom Management control and disciplin

Classroom Management

Classroom Management

Classroom Management-Getting students to respect them and follow through

I feel that college students need to have a strong disipline plan in place. I understand every school is different\&it hasn't been a huge issue with my past student teachers but it is essential with all

classrooms.

Difficulty with classroom management/behavioral strategies

Understanding classroom management

Knowing how to handle discipline problems when they happen.

Handling situations where students "test" a student teacher's authority in the classroom

Classroom Management

Behavior Management

Classroom behavior management-Being able to control classroom or redirect student focus. Seeing everything that is happening.

Some of them had trouble with control in class.

Baseline knowledge of curriculum and the inability to research information to counteract depth of knowledge.

Classroom teaching content ( Ag. Mech, Animal, \& Plant Science).

Depth of Knowledge

Experience in Agriculture.

Lack of content knowledge, student teachers are coming with very little practical experience in some of the content areas. Mechanics and running a greenhouse are 2 examples.

Depth of specific curriculum knowledge-Delivery was good but need to spend more time researching \& practicing skills/knowledge to be taught.

Depth of content knowledge is low.

FFA background/experience.

Lack of record book experience (both in paper \& AET).

SAE

Record book knowledge-AET.

Depth of knowledge in agriculture mechanics.

Lack of Ag. Mech. Knowledge

Lacking confidence in the shop.

Engagement \& diversity-Differentiating instruction that engages students and helps them progress.

Understanding differentiated instruction

Incorporating the demands of student IEPs into the lesson plans that they must develop.

At first students have trouble bring the infromation down to the high school level.

Modifying tests and activities for students with an IEP.

Hard for them to teach a wide variety of students with different skill levels.

Utilizing resources-Not asking cooperating teacher questions maybe being afraid to ask in areas of weakness, not practicing or getting extra help.

dapting class activities or programs.

Diversification of lesson research methods: Using resources like communities of practice, lesson plan data base from other states, etc to prevent reinvention of wheel.

Sesson preparation.

inding reliable resources to use for lesson plans.

ack of research in the area to be taught.

rofessionalism

bility to understand boundaries of teacher-student relationships.

ecoming too comfortable or friendly with students

At their youthful age, being able to ward off or redirect flirting by students.

Meeting the specific teaching style expectations of the cooperating teacher.

The effort to develop a teaching style when a cooperating teacher is not willing to give control.

Connecting content-relating material to real world application or to students current level of experiences.

Keeping students engaged.

Unrealistic expectations from WVU as far as what happens the 3 weeks prior to student teaching. Many times student teachers are still buried in that work while trying to teach full time.

Trying to keep up WVU level lesson plans while taking part in the sfter school meetings and team trainin.

Destractions from intended topics due to over-riding instruction from cooperating teacher and administration.

Total time commitment to career-Its not a 9-5 job, afterschool activities.

Adjusting to the abnormal schedule: pulling students out of class orr assemblies, etc.

Financial-Student teachers have some troubles being able to afford to student tea

Living arrangements and distance from school. 50-60 minutes from WVU.

Absences and tardies seem to get worse every year. Student teachers need to be aware of this\&make all assignments\&make-up work avaliable for the students to access at will. Adhere to county policies

be strict about timelines for making up assignments\&leave it up toe the student. If it is past due, too bad.

Student behavior and apathy. Student teachers were not prepared for the challenge of students that didn't want to be in class and not caring at all about passing or failing the class.

Organization of FFA activities.

Desire to grade everything rather than identify hinge assignments for summative grade.

Parent involvement.

Dealing with parents who think that a student teachers is dealing unfaily with their child. 
Challenges Cooperating Teachers Faced

Expectations with after FFA events.

Program involvement.

Getting the student teacher involved in local chapter and ag. activities.

Student teachers who did not want to spend time after school w/FFA activities (this is part of the job being and ag. teacher).

Dealing with evening/weekend expectations of the job.

SAE supervision skills.

Ag teachers don't have a time clock. We work until the job is done.

School finance.

Materials-Ability to provide all materials that a student teacher might need for their lesson (funding).

At times having enough supplies on hand for them to conduct successful labs \& hands on activities-takes a lot of preplanning.

Ensuring that students are delivered their individualized education program.

Communication-Ability to show student teachers my vision.

Remembering that just because it is not being done the way I would do it does not mean it is incorrect.

Knowing when to help or knowing how much help to give a student teachers when challenges arise concerning student behavior and parental conflict.

It was more work on my part than expected, because I had to ensure the content was making a connection to my students. I found myself chiming in on class more often than I felt I should. I was afraid of overstepping my bounds as an observer, not wanting to diminish the authority of the student teacher.

Supervise the student teacher in the classroom session with out butting in while teaching.

Letting go of class-Not repremanding bad behavior when student teacher is teaching is hard.

Allowing the student teacher freedom to develop their own lesson plans while making certain that my students were going to receive the training \& info necessary for them to be successful in

the ensuing lessons that I would teach later on.

Allowing student teachers the lattitude to make mistakes so as they learn from them and grow.

Lack of preparedness-Helping student teeacher get stuff going or fill in tiem when they should have more.

Getting the student teachers to understand what they were teaching was incorrect. There was also an unwillingness to correct the mistakes.

Not willing to make sure what they were teaching was correct.

Lack of knowledge of some student teachers of what it takes to fun all three components of theis program.

Making certain content deliveered was what I wanted my students to absorb.

Unit development: I have given student teacher free will to choose a unit to teache and I still had to come up with ideas.

Student teacher not doing what they were required to. Example-Turning in of lesson plans before the subject is taught.

Use of cell phone, against school rules.

Getting them to do lesson plans more than 24 hours in advance.

Lack of teaching interest-Student teacer didn't care or want to be a teacher.

Student teachers who did not want to be student teaching or theyought they "knew it all".

Not willing to take advice.

Assuming they already knew how to do something so they don't help the cooperative teacher do it.

Too confrontational to criticisim.

Classroom Management

Finding ways to encourage sudent teachers to "drop the hammer" on problem students.

Lack of understanding of student control during classtime and in greenhouse.

Keeping student on task when first transition to pre-service teacher.

Feeder school, kids coming and going.

Managing laboratory spaces-greenhouse, shop, barn, meats lab.

Communication of WVU expectations.

Keeping up with paperwork and feedback to WVU.

Remembering to complete the weekly evaluation.

Facilitating absences when student teacher has seminars at WVU causing continuity issues with lesson.

Lack of time to work with student teachers one on one.

Change of normal after school schedule to help meet pre-service teacher needs.

Giving negative feedback.

Confidentiality in evaluationg student teacher while providing positive feedback.

Having enough time to provide meaninful feedback and conduct classes, teach, plan, etc.

Managing time to confer with student while not interferring with planning tiem and prep time.

Encouraging student teachers to step out of their comfort zones-Teach the parts of agriculture that they are not married to.

Merging my techniques of teaching in a lab setting with those of "freshman" teachers.

Personal Relationships.

Knowing the students.

Supporting vulnerable students.

Safety: I was gone, student teacher allowed students to use tools, came back to an accident report.

Disgruntled students-Ability to communicate why my teaching methodology is not being used after signing up for my class.

Feeling like I didn't give them a positive experience because they did not seem to leave student teaching with a burning passion to teach.

Trouble showing up on time.

Ag. Math...Many students are challenged by math but it is a mandate for ag. Teachers to teach it, they need to learn it.

Accountability for students who are absent. 
APPENDIX E

Phase II Survey 


\title{
CHALLENGES PERCEIVED BY COOPERATING TEACHERS
}

\section{WHILE SUPERVISING PRESERVICE TEACHERS}

\author{
Phase Two
}

The first section of this survey relates to whether or not you observed the following to be significant challenges your pre-service teachers faced during the student teacher experience. When considering the challenges pleas focus on student teachers you have supervised from West Virginia University's Agricultural and Extension Education department between 2006-2016. If you have had multiple student teachers over these years please answer "YES" if you have observed the challenge in at least 1 of your student teachers. Please circle either YES or NO.

Do you agree...

That classroom management was a significant challenge your pre-service YES NO teacher(s) faced?

That getting secondary students to respect them as a teacher was a

YES

NO

significant challenge your pre-service teacher(s) faced?

That knowing how to handle discipline problems when they arise was a YES NO significant challenge your pre-service teacher(s) faced?

That not having a strong discipline plan in place was a significant challenge your pre-service teacher(s) faced?

YES NO

That time management was a significant challenge your pre-service teacher(s) faced?

YES NO

That adjusting an abnormal schedule due to assemblies, students YES NO leaving class, etc. was a significant challenge your pre-service teacher(s) faced?

That teaching the entire class period was a significant challenge your pre-service teacher(s) faced?

That understanding the amount of time it takes to prepare for a full YES NO day of teaching was a significant challenge your pre-service teacher(s) faced?

That not being prepared to handle secondary students who did not YES NO want to be in the class was a significant challenge your pre-service teacher(s) faced?

That lack of proper planning was a significant challenge your pre-service YES NO teacher(s) faced? 
That lesson preparation was a significant challenge your pre-service challenge your pre-service teacher(s) faced?

Please circle YES or NO if you observed the following to be significant challenges your pre-service teacher(s) faced while student teaching.

Do you agree...

That not researching the content they are teaching was a significant challenge your pre-service teacher(s) faced?

YES NO

That the depth of knowledge of the content area was a significant

YES NO challenge your pre-service teacher(s) faced?

That lack of confidence in the classroom was a significant challenge your YES NO pre-service teacher(s) faced?

That lack of record book knowledge was a significant challenge your pre-service teacher(s) faced?

YES NO

That lack of FFA experience was a significant challenge your pre-service teacher(s) faced?

That organizing FFA activities was a significant challenge your preservice teacher(s) faced?

That lack of greenhouse knowledge was a significant challenge your preservice teacher(s) faced?

That lack of plant science knowledge was a significant challenge your pre-service teacher(s) faced?

That lack of knowledge in agricultural mechanics was a significant

That lack of confidence in the shop was a significant challenge your preservice teacher(s) faced?

That lack of knowledge in animal science was a significant challenge your pre-service teacher(s) faced?

YES NO

That the total time commitment to the job was a significant challenge your pre-service teacher(s) faced?

That meeting the teaching style expectations of the cooperating teacher YES NO was a significant challenge your pre-service teacher(s) faced? 

give a participation grade or provide feedback was a significant challenge your pre-service teacher(s) faced?

Please circle YES or NO if you observed the following to be significant challenges your pre-service teacher(s) faced while student teaching.

Do you agree...

That connecting content to real world applications was a significant challenge your pre-service teacher(s) faced?

YES NO

That keeping students engaged was a significant challenge your preservice teacher(s) faced?

That teaching students with different skill levels was a significant challenge your pre-service teacher(s) faced?

That differentiating instruction was a significant challenge your preservice teacher(s) faced?

That meeting the needs of a student's individualized education programs (IEPs) was a significant challenge that your pre-service teacher(s) faced?

That distractions from intended topics due to the cooperating teacher was a significant challenge your pre-service teacher(s) faced?

That distractions from intended topics due to administration was a significant challenge your pre-service teacher(s) faced?

YES NO

YES NO

YES NO

YES NO

That professionalism was a significant challenge your pre-service teacher(s) faced?

That being able to ward off or redirect flirting by students was a significant challenge your pre-service teacher(s) faced?

YES NO

YES NO

That understanding boundaries of teacher-student relationships was a significant challenge your pre-service teacher(s) faced?

That being able to earn an income during their internship was a significant challenge your pre-service teacher(s) faced?

YES NO

That the distance the school is from WVU was a significant challenge YES NO your pre-service teacher(s) face?

That living arrangements was a significant challenge your pre-service $\quad$ YES NO teacher(s) faced?

That dealing with secondary students absences was a significant YES NO challenge your pre-service teacher(s) faced? 
Please circle YES or NO if you observed the following to be significant challenges your pre-service teacher(s) faced while student teaching.

Do you agree...

That parent involvement was a significant challenge your pre-service teacher(s) faced?

YES NO

That dealing with parents who felt their child was being treated

YES NO

unfairly was a significant challenge your pre-service teacher(s) faced?

That trying to keep up WVU level lesson plans was a significant

YES NO

challenge your pre-service teacher(s) faced?

That WVU's expectation in being buried in work from the 3 weeks

YES NO

prior to student teaching was a significant challenge your pre-service teacher(s) faced?

That the staggered arrival and dismissal times of tech center students

YES NO was a significant challenge your pre-service teacher(s) faced? 
The second section of this survey relates to whether or not you perceived the following to be significant challenges that you encountered as a cooperating teacher while supervising a pre-service teacher. Please keep your answers limited to pre-service teacher(s) you have supervised from West Virginia University’s Agricultural and Extension Education department between 2006-2016. Please circle YES or NO.

Do you agree...

That pre-planning far enough in advance to secure the materials for YES NO the lessons of your pre-service teacher(s) was a significant challenge you faced as a cooperating teacher?

That the lack of time to share feedback with pre-service teacher(s) was a significant challenge you faced as a cooperating teacher?

That your pre-service teacher(s) not showing up on time was a significant challenge you faced as a cooperating teacher?

YES NO

YES NO

That filling in for your pre-service teacher(s) when they have to miss

YES NO due to seminars at WVU was a significant challenge you faced as a cooperating teacher?

That filling in for your pre-service teacher(s) when they have to miss due to unexpected absences was a significant challenge you faced as a cooperating teacher?

That lack of preparedness by your pre-service teacher(s) to fill entire YES NO class time was a significant challenge you faced as a cooperating teacher?

That your pre-service teacher(s) not having their lesson plans prepared more than 24 hours in advance was a significant challenge you faced as a cooperating teacher?

That having pre-service teacher(s) who did not understand the time YES NO commitment that comes with being an agricultural instructor was a significant challenge you faced as a cooperating teacher?

That the understanding of your pre-service teacher(s) of the time YES NO commitment needed to run the total program was a significant challenge you faced as a cooperating teacher?

That the lack of knowledge your pre-service teacher(s) possessed about YES NO the total program was a significant challenge you faced as a cooperating teacher?

That merging your lab setting techniques with the techniques of your $\quad$ YES NO pre-service teacher(s) was a significant challenge you faced as a cooperating teacher? 
That remembering content could still be correct even when your preservice teacher(s) did not teach it the same way you would have was a significant challenge you faced as a cooperating teacher?

Please circle YES or NO if the following were challenges you faced as a cooperating teacher while supervising a student teacher.

Do you agree...

That having to communicate to your secondary students why they were not being taught by you was a significant challenge you faced as a cooperating teacher?

That pre-service teacher(s) not holding secondary students accountable for work when they were absent was a significant challenge you faced as a cooperating teacher?

That you had to "chime in" on the lessons your pre-service teacher(s)

YES

NO taught more than you should have was a significant challenge you faced as a cooperating teacher?

That allowing your pre-service teacher(s) to make mistakes so they could grow from it was a significant challenge you faced as a cooperating teacher?

That transitioning your secondary students from you being the

teachers to your pre-service teacher(s) was a significant challenge you faced as a cooperating teacher?

That encouraging your pre-service teacher(s) to discipline problem students was a significant challenge you faced as a cooperating teacher?

That the management of secondary students by you pre-service teacher(s) in the laboratory settings (greenhouse, shop, barn, meats lab, etc.) was a significant challenge you faced as a cooperating teacher?

That the lack of interest your pre-service teacher(s) had to be future educators was a significant challenge you faced as a cooperating teacher?

That the attitude your pre-service teacher(s) had about "knowing it YES

NO all” was a significant challenge you faced as a cooperating teacher?

That the unwillingness of your pre-service teacher(s) to take advice was a significant challenge you faced as a cooperating teacher?

That the enthusiasm level of your pre-service teacher(s) to keep YES NO secondary students engaged was a significant challenge you faced as a cooperating teacher? 

teacher?

That your pre-service teacher(s) not following school rules (cell phone use, dress code, etc.) was a significant challenge you faced as a cooperating teacher?

That your pre-service teacher(s) getting to know the students was a significant challenge you faced as a cooperating teacher?

Please circle YES or NO if the following were challenges you faced as a cooperating teacher while supervising a student teacher.

Do you agree...

That communicating your vision to your pre-service teacher(s) was a

significant challenge you faced as a cooperating teacher?

That ensuring the pre-service teacher(s) were delivering individualized education programs (IEPs) to your secondary students was a

significant challenge you faced as a cooperating teacher?

That the ability of your pre-service teacher(s) to monitor safety was a significant challenge you faced as a cooperating teacher?

That making sure that your secondary students were being taught

you faced as a cooperating teacher?

That encouraging your pre-service teacher(s) to step outside of their comfort zones was a significant challenge you faced as a cooperating teacher?

That ensuring your pre-service teacher(s) made the connection from faced as a cooperating teacher?

That knowing when to help your pre-service teacher(s) when a faced as a cooperating teacher?

That knowing when to help your pre-service teacher(s) when an issue 

an issue occurred with parental conflict was a significant challenge you faced as a cooperating teacher?

That the fear of overstepping your boundaries as an observer was a

YES

NO

significant challenge you faced as a cooperating teacher?

That an unwillingness from your pre-service teacher(s) to make

YES NO corrections to the content they were teaching was a significant challenge you faced as a cooperating teacher?

That the lack of mathematical knowledge the pre-service teacher(s)

YES NO exhibited was a significant challenge you faced as a cooperating teacher?

That the correctness of the lessons your pre-service teacher(s) was a YES

NO significant challenge you faced as a cooperating teacher?

Please circle YES or NO if the following were challenges you faced as a cooperating teacher while supervising a student teacher.

Do you agree...

That keeping up with the feedback paperwork from WVU was a

YES NO significant challenge you faced as a cooperating teacher?

That remembering to complete the weekly evaluations of your preYES NO service teacher(s) was a significant challenge you faced as a cooperating teacher?

That WVU's communication of their expectations was a significant YES NO challenge you faced as a cooperating teacher?

That providing pre-service teacher(s) with materials they would need for lessons was a significant challenge you faced as a cooperating teacher?

Please complete the survey, place in the return envelope, and mail back by April 19, 2017. Phase Three will be provided in a few weeks. If you are willing to take that electronically through email, please provide one where we can contact you. Thank You! 


\section{APPENDIX F}

Phase II Cover Letter 
April 10, 2017

Dear Cooperating Teacher:

A few weeks ago we sent you an open ended survey to discuss your thoughts on what you perceived to be challenges as a cooperating teacher. We have analyzed that data and have comprised the second part of the survey.

I am Samantha Cogle, a graduate student in Agricultural and Extension Education. Under the direction of my advisor, Dr. Stacy Gartin, we are conducting a study to determine the challenges that cooperating teachers encounter when supervising a student teacher. The results of this study will be used to prepare a thesis to partially fulfill the requirements of a Master of Science in Agricultural and Extension Education. We are contacting agricultural educators who have served as cooperating teachers for West Virginia University's agricultural education pre-service teachers between the years 2011 and 2016. The results will provide information to teacher educators in order to help better manage the student teacher experience.

Participation in this research study is completely voluntary and all information you provide will be held as confidential as possible. This study will be conducted in three phases with this being the second. This survey should only take about 8 minutes to complete. Your response is crucial to the success of the study. You may skip the question if you are not comfortable answering and you may stop at any time. Survey results will be reported in a summary format and individual responses will not be identifiable.

The Institutional Review Board (IRB) at West Virginia University has approved this study Protocol \#1702458725. If you have any questions or concerns about completing the questionnaire or about participating in this study, you may contact me at scogle@mix.wvu.edu or (304) 641-5548.

Please complete your survey before April 19, 2017. Thank you in advance for your assistance with this study, we sincerely appreciate your participation.

Respectfully yours,

Samantha L. Cogle

Graduate Student

Agricultural and Extension Education

Education
Stacy A. Gartin, Ph.D.

Professor

Agricultural and Extension 
APPENDIX G

Phase II Results 


\begin{tabular}{|c|c|c|c|c|c|}
\hline Question & Total Response & Yes & Percent Yes & No & Percent No \\
\hline 1 & 14 & 12 & $86 \%$ & 2 & $14 \%$ \\
\hline 2 & 14 & 7 & $50 \%$ & 7 & $50 \%$ \\
\hline 3 & 14 & 10 & $71 \%$ & 4 & $29 \%$ \\
\hline 4 & 14 & 10 & $71 \%$ & 4 & $29 \%$ \\
\hline 5 & 14 & 9 & $64 \%$ & 5 & $36 \%$ \\
\hline 6 & 14 & 3 & $21 \%$ & 11 & $79 \%$ \\
\hline 7 & 14 & 6 & $43 \%$ & 8 & $57 \%$ \\
\hline 8 & 14 & 7 & $50 \%$ & 7 & $50 \%$ \\
\hline 9 & 14 & 9 & $64 \%$ & 5 & $36 \%$ \\
\hline 10 & 14 & 6 & $43 \%$ & 8 & $57 \%$ \\
\hline 11 & 14 & 8 & $57 \%$ & 6 & $43 \%$ \\
\hline 12 & 14 & 6 & $43 \%$ & 8 & $57 \%$ \\
\hline 13 & 14 & 4 & $29 \%$ & 10 & $71 \%$ \\
\hline 14 & 14 & 9 & $64 \%$ & 5 & $36 \%$ \\
\hline 15 & 14 & 4 & $29 \%$ & 10 & $71 \%$ \\
\hline 16 & 13 & 8 & $62 \%$ & 5 & $38 \%$ \\
\hline 17 & 14 & 3 & $21 \%$ & 11 & $79 \%$ \\
\hline 18 & 14 & 1 & $7 \%$ & 13 & $93 \%$ \\
\hline 19 & 13 & 6 & $46 \%$ & 7 & $54 \%$ \\
\hline 20 & 13 & 3 & $23 \%$ & 10 & $77 \%$ \\
\hline 21 & 13 & 7 & $54 \%$ & 6 & $46 \%$ \\
\hline 22 & 13 & 6 & $46 \%$ & 7 & $54 \%$ \\
\hline 23 & 12 & 2 & $17 \%$ & 10 & $83 \%$ \\
\hline 24 & 14 & 8 & $57 \%$ & 6 & $43 \%$ \\
\hline 25 & 14 & 5 & $36 \%$ & 9 & $64 \%$ \\
\hline 26 & 14 & 5 & $36 \%$ & 9 & $64 \%$ \\
\hline 27 & 13 & 2 & $15 \%$ & 11 & $85 \%$ \\
\hline 28 & 13 & 7 & $54 \%$ & 6 & $46 \%$ \\
\hline 29 & 13 & 8 & $62 \%$ & 5 & $38 \%$ \\
\hline 30 & 14 & 8 & $57 \%$ & 6 & $43 \%$ \\
\hline 31 & 13 & 6 & $46 \%$ & 7 & $54 \%$ \\
\hline 32 & 13 & 1 & $8 \%$ & 12 & $92 \%$ \\
\hline 33 & 13 & 0 & $0 \%$ & 13 & $100 \%$ \\
\hline 34 & 13 & 3 & $23 \%$ & 10 & $77 \%$ \\
\hline 35 & 13 & 2 & $15 \%$ & 11 & $85 \%$ \\
\hline 36 & 13 & 3 & $23 \%$ & 10 & $77 \%$ \\
\hline 37 & 13 & 2 & $15 \%$ & 11 & $85 \%$ \\
\hline 38 & 13 & 3 & $23 \%$ & 10 & $77 \%$ \\
\hline 39 & 13 & 2 & $15 \%$ & 11 & $85 \%$ \\
\hline 40 & 13 & 4 & $31 \%$ & 9 & $69 \%$ \\
\hline 41 & 13 & 4 & $31 \%$ & 9 & $69 \%$ \\
\hline 42 & 13 & 1 & $8 \%$ & 12 & $92 \%$ \\
\hline 43 & 13 & 2 & $15 \%$ & 11 & $85 \%$ \\
\hline
\end{tabular}




\begin{tabular}{|c|c|c|c|c|c|}
\hline Question & Total Response & Yes & Percent Yes & No & Percent No \\
\hline 44 & 11 & 8 & $73 \%$ & 3 & $27 \%$ \\
\hline 45 & 11 & 4 & $36 \%$ & 7 & $64 \%$ \\
\hline 46 & 11 & 1 & $9 \%$ & 10 & $91 \%$ \\
\hline 47 & 14 & 8 & $57 \%$ & 6 & $43 \%$ \\
\hline 48 & 14 & 7 & $50 \%$ & 7 & $50 \%$ \\
\hline 49 & 14 & 3 & $21 \%$ & 11 & $79 \%$ \\
\hline 50 & 14 & 2 & $14 \%$ & 12 & $86 \%$ \\
\hline 51 & 14 & 2 & $14 \%$ & 12 & $86 \%$ \\
\hline 52 & 14 & 5 & $36 \%$ & 9 & $64 \%$ \\
\hline 53 & 14 & 6 & $43 \%$ & 8 & $57 \%$ \\
\hline 54 & 14 & 8 & $57 \%$ & 6 & $43 \%$ \\
\hline 55 & 14 & 9 & $64 \%$ & 5 & $36 \%$ \\
\hline 56 & 14 & 5 & $36 \%$ & 9 & $64 \%$ \\
\hline 57 & 14 & 6 & $43 \%$ & 8 & $57 \%$ \\
\hline 58 & 14 & 2 & $14 \%$ & 12 & $86 \%$ \\
\hline 59 & 14 & 5 & $36 \%$ & 9 & $64 \%$ \\
\hline 60 & 14 & 2 & $14 \%$ & 12 & $86 \%$ \\
\hline 61 & 14 & 2 & $14 \%$ & 12 & $86 \%$ \\
\hline 62 & 14 & 5 & $36 \%$ & 9 & $64 \%$ \\
\hline 63 & 14 & 4 & $29 \%$ & 10 & $71 \%$ \\
\hline 64 & 14 & 2 & $14 \%$ & 12 & $86 \%$ \\
\hline 65 & 14 & 4 & $29 \%$ & 10 & $71 \%$ \\
\hline 66 & 14 & 2 & $14 \%$ & 12 & $86 \%$ \\
\hline 67 & 14 & 2 & $14 \%$ & 12 & $86 \%$ \\
\hline 68 & 14 & 4 & $29 \%$ & 10 & $71 \%$ \\
\hline 69 & 14 & 4 & $29 \%$ & 10 & $71 \%$ \\
\hline 70 & 14 & 3 & $21 \%$ & 11 & $79 \%$ \\
\hline 71 & 14 & 0 & $0 \%$ & 14 & $100 \%$ \\
\hline 72 & 14 & 2 & $14 \%$ & 12 & $86 \%$ \\
\hline 73 & 14 & 1 & $7 \%$ & 13 & $93 \%$ \\
\hline 74 & 14 & 5 & $36 \%$ & 9 & $64 \%$ \\
\hline 75 & 14 & 2 & $14 \%$ & 12 & $86 \%$ \\
\hline 76 & 14 & 4 & $29 \%$ & 10 & $71 \%$ \\
\hline 77 & 14 & 4 & $29 \%$ & 10 & $71 \%$ \\
\hline 78 & 14 & 1 & $7 \%$ & 13 & $93 \%$ \\
\hline 79 & 14 & 3 & $21 \%$ & 11 & $79 \%$ \\
\hline 80 & 13 & 3 & $23 \%$ & 10 & $77 \%$ \\
\hline 81 & 14 & 4 & $29 \%$ & 10 & $71 \%$ \\
\hline 82 & 13 & 3 & $23 \%$ & 10 & $77 \%$ \\
\hline 83 & 14 & 5 & $36 \%$ & 9 & $64 \%$ \\
\hline 84 & 14 & 2 & $14 \%$ & 12 & $86 \%$ \\
\hline 85 & 14 & 1 & $7 \%$ & 13 & $93 \%$ \\
\hline 86 & 14 & 2 & $14 \%$ & 12 & $86 \%$ \\
\hline
\end{tabular}




\begin{tabular}{lccccc}
\hline Question & Total Response & Yes & Percent Yes & No & Percent No \\
\hline 87 & 14 & 3 & $21 \%$ & 11 & $79 \%$ \\
88 & 14 & 6 & $43 \%$ & 8 & $57 \%$ \\
89 & 14 & 1 & $7 \%$ & 13 & $93 \%$ \\
90 & 14 & 2 & $14 \%$ & 12 & $86 \%$ \\
\hline
\end{tabular}




\section{APPENDIX $\mathrm{H}$}

Phase III Survey 
Challenges Perceived by Cooperating Teachers

while Supervising Student Teachers

Phase 3 of a Modified Delphi Study

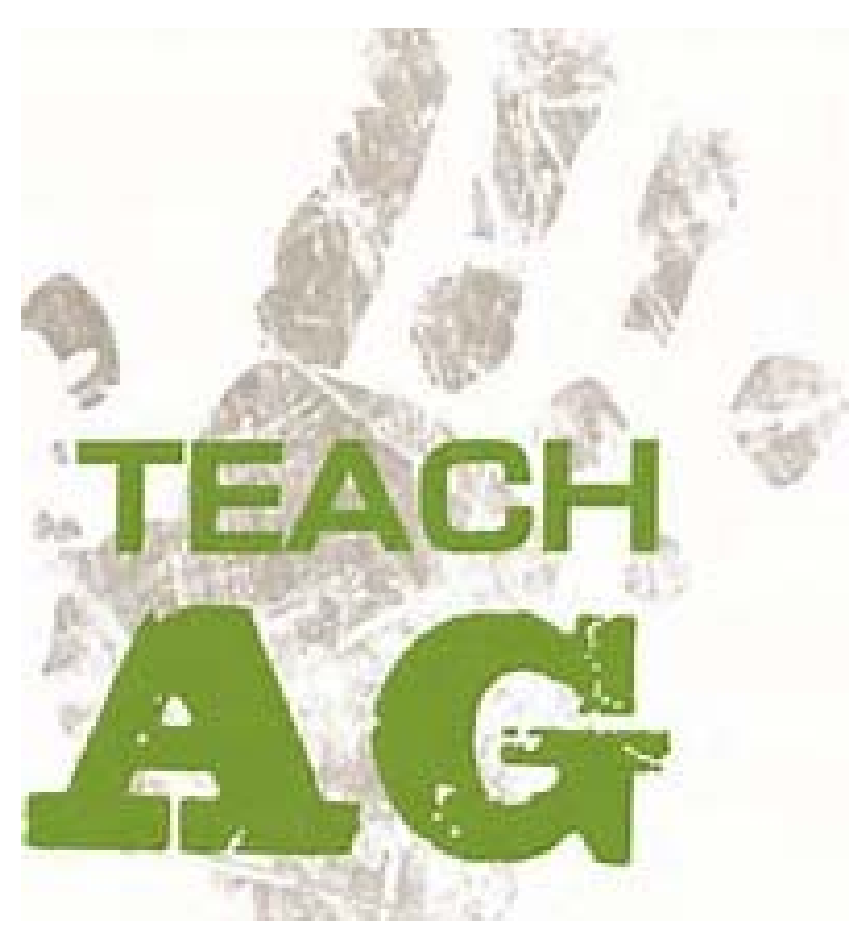

Samantha Cogle

Graduate Student

Agricultural and Extension Education

Davis College of Agriculture, Natural Resources, and Design

West Virginia University 
The first section of this survey relates to challenges you identified in the pre-service teachers you supervised between 2006-2016.

Please read each statement and rate it on the significance of that problem as well as the frequency that it occurred with those pre-service teachers.

Please use the following scale for rating the significance of the problem:

1-Not Applicable, 2-Not a problem, 3-Minor problem, 4-Moderate problem, and 5-

Serious problems.

Please use the following scale for rating the frequency that the problem occurred with your pre-service teachers: 1- Not Applicable, 2- Never, 3- Occasionally/Sometimes, 4Almost Every time, 5- Every time.

\begin{tabular}{|c|c|c|c|c|c|c|c|c|c|c|}
\hline \multirow{2}{*}{$\begin{array}{l}\text { Read the following and circle the } \\
\text { number that corresponds to the rating } \\
\text { you would give it on significance of it } \\
\text { being a problem and then on the } \\
\text { frequency it occurred for your pre- } \\
\text { service teacher(s) as a problem. }\end{array}$} & \multicolumn{5}{|c|}{$\begin{array}{c}\text { Significance of } \\
\text { Problem }\end{array}$} & \multicolumn{5}{|c|}{$\begin{array}{l}\text { Frequency of } \\
\text { Problem }\end{array}$} \\
\hline & $\overleftrightarrow{\square}$ & 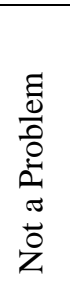 & 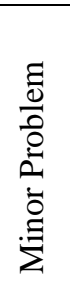 & 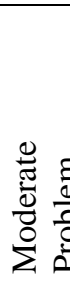 & 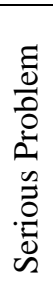 & $\overleftrightarrow{\square}$ & 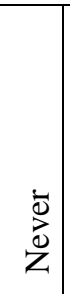 & 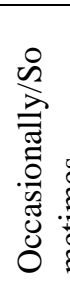 & 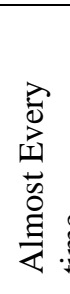 & 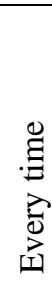 \\
\hline $\begin{array}{l}\text { 1. Pre-service teacher(s) classroom } \\
\text { management was/occurred... }\end{array}$ & 1 & 2 & 3 & 4 & 5 & 1 & 2 & 3 & 4 & 5 \\
\hline $\begin{array}{l}\text { 2. Pre-service teacher(s) knowing } \\
\text { how to handle discipline problems } \\
\text { when they arise was/occurred... }\end{array}$ & 1 & 2 & 3 & 4 & 5 & 1 & 2 & 3 & 4 & 5 \\
\hline $\begin{array}{l}\text { 3. Pre-service teacher(s) not having a } \\
\text { strong discipline plan in place } \\
\text { was/occurred... }\end{array}$ & 1 & 2 & 3 & 4 & 5 & 1 & 2 & 3 & 4 & 5 \\
\hline $\begin{array}{l}\text { 4. Pre-service teacher(s) not being } \\
\text { prepared to handle secondary } \\
\text { students who did not want to be in } \\
\text { the class was/occurred... }\end{array}$ & 1 & 2 & 3 & 4 & 5 & 1 & 2 & 3 & 4 & 5 \\
\hline $\begin{array}{l}\text { 5. Pre-service teacher(s) time } \\
\text { management was/occurred... }\end{array}$ & 1 & 2 & 3 & 4 & 5 & 1 & 2 & 3 & 4 & 5 \\
\hline $\begin{array}{l}\text { 6. Pre-service teacher(s) total time } \\
\text { commitment to the job } \\
\text { was/occurred... }\end{array}$ & 1 & 2 & 3 & 4 & 5 & 1 & 2 & 3 & 4 & 5 \\
\hline $\begin{array}{l}\text { 7. Pre-service teacher(s) lesson } \\
\text { preparation was/occurred... }\end{array}$ & 1 & 2 & 3 & 4 & 5 & 1 & 2 & 3 & 4 & 5 \\
\hline
\end{tabular}




\begin{tabular}{|l|c|c|c|c|c|c|c|c|c|c|}
\hline & & & & & & & & & &
\end{tabular}

\begin{tabular}{|c|c|c|c|c|c|c|c|c|c|c|}
\hline \multirow[b]{2}{*}{$\begin{array}{l}\text { Read the following statements and } \\
\text { circle the number that corresponds to } \\
\text { the rating you would give it on } \\
\text { significance of it being a problem and } \\
\text { then on the frequency it occurred for } \\
\text { your pre-service teacher(s) as a } \\
\text { problem. }\end{array}$} & \multicolumn{5}{|c|}{$\begin{array}{c}\text { Significance of } \\
\text { Problem }\end{array}$} & \multicolumn{5}{|c|}{$\begin{array}{l}\text { Frequency of } \\
\text { Problem }\end{array}$} \\
\hline & $\mathbb{3}$ & 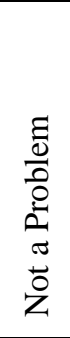 & 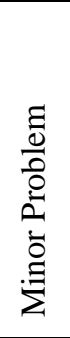 & 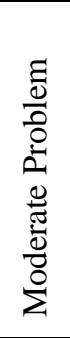 & 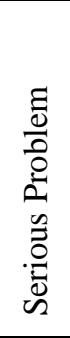 & 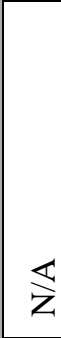 & $\begin{array}{c}\overrightarrow{\tilde{\nu}} \\
\stackrel{\Delta}{z}\end{array}$ & 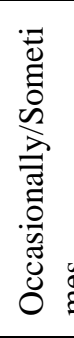 & 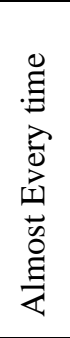 & 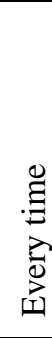 \\
\hline $\begin{array}{l}\text { 10. Pre-service teacher(s) ability to } \\
\text { teach students with different skill } \\
\text { levels was/occurred... }\end{array}$ & 1 & 2 & 3 & 4 & 5 & 1 & 2 & 3 & 4 & 5 \\
\hline $\begin{array}{l}\text { 11. Pre-service teacher(s) ability to } \\
\text { differentiate instruction } \\
\text { was/occurred... }\end{array}$ & 1 & 2 & 3 & 4 & 5 & 1 & 2 & 3 & 4 & 5 \\
\hline $\begin{array}{l}\text { 12. Pre-service teacher(s) lack of } \\
\text { record book knowledge } \\
\text { was/occurred... }\end{array}$ & 1 & 2 & 3 & 4 & 5 & 1 & 2 & 3 & 4 & 5 \\
\hline $\begin{array}{l}\text { 13. Pre-service teacher(s) lack of } \\
\text { knowledge in agricultural } \\
\text { mechanics was/occurred... }\end{array}$ & 1 & 2 & 3 & 4 & 5 & 1 & 2 & 3 & 4 & 5 \\
\hline $\begin{array}{l}\text { 14. Pre-service teacher(s) depth of } \\
\text { knowledge of the content area } \\
\text { was/occurred... }\end{array}$ & 1 & 2 & 3 & 4 & 5 & 1 & 2 & 3 & 4 & 5 \\
\hline
\end{tabular}


Please use a 1-5 scale to rate the average proficiency of your student teachers in the following content areas.

1- Not Applicable, 2- Not Proficient, 3- Somewhat Proficient, 4- Moderately Proficient, 5- Extremely Proficient.

Please circle the rating that best describes the average content area proficiency of your pre-service teachers that you supervised between 2006-2016.

\begin{tabular}{|l|c|c|c|c|c|}
\hline \multicolumn{1}{|c|}{ Content Area } & $\begin{array}{c}\text { Not } \\
\text { Applicable }\end{array}$ & $\begin{array}{c}\text { Not } \\
\text { Proficient }\end{array}$ & $\begin{array}{c}\text { Somewhat } \\
\text { Proficient }\end{array}$ & $\begin{array}{c}\text { Moderately } \\
\text { Proficient }\end{array}$ & $\begin{array}{c}\text { Extremely } \\
\text { Proficient }\end{array}$ \\
\hline $\begin{array}{l}\text { 15. Agricultural } \\
\text { Mechanics }\end{array}$ & 1 & 2 & 3 & 4 & 5 \\
\hline $\begin{array}{l}\text { 16. Agricultural } \\
\text { Business }\end{array}$ & 1 & 2 & 3 & 4 & 5 \\
\hline 17. FFA/SAE & 1 & 2 & 3 & 4 & 5 \\
\hline $\begin{array}{l}\text { 18. Food/Meat } \\
\text { Science }\end{array}$ & 1 & 2 & 3 & 4 & 5 \\
\hline $\begin{array}{l}\text { 19. Large Animal } \\
\text { Science }\end{array}$ & 1 & 2 & 3 & 4 & 5 \\
\hline $\begin{array}{l}\text { 20. Small Animal } \\
\text { Science }\end{array}$ & 1 & 2 & 3 & 4 & 5 \\
\hline 21. Forestry & 1 & 2 & 3 & 4 & 5 \\
\hline 22. Natural Resources & 1 & 2 & 3 & 4 & 5 \\
\hline 23. Plant Science & 1 & 2 & 3 & 4 & 5 \\
\hline 24. Soil Science & 1 & 2 & 3 & 5 \\
\hline $\begin{array}{l}\text { 25. Greenhouse } \\
\text { Management }\end{array}$ & 1 & & & 4 & 5 \\
\hline
\end{tabular}

The second section of this survey relates to challenges you identified that you encountered as the cooperating teacher while supervising pre-service teachers you between 2006-2016.

Please read each statement and rate it on the significance of that problem as well as the frequency that it occurred as a cooperating teacher.

Please use the following scale for rating the significance of the problem:

1-Not Applicable, 2-Not a problem, 3-Minor problem, 4-Moderate problem, and 5Serious problems.

Please use the following scale for rating the frequency that the problem occurred as a cooperating teacher: 
1- Not Applicable, 2- Never, 3- Occasionally/Sometimes, 4- Almost Every time, 5- Every time.

\begin{tabular}{|c|c|c|c|c|c|c|c|c|c|c|}
\hline \multirow[b]{2}{*}{$\begin{array}{l}\text { Read the following statements and } \\
\text { circle the number that corresponds to } \\
\text { the rating you would give it on } \\
\text { significance of the problem and then } \\
\text { on the frequency it occurred as a } \\
\text { cooperating teacher. }\end{array}$} & \multicolumn{5}{|c|}{$\begin{array}{c}\begin{array}{c}\text { Significance of } \\
\text { Problem }\end{array} \\
\end{array}$} & \multicolumn{5}{|c|}{$\begin{array}{c}\text { Frequency of } \\
\text { Problem }\end{array}$} \\
\hline & $\overleftrightarrow{z}$ & 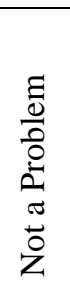 & 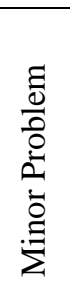 & 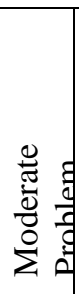 & 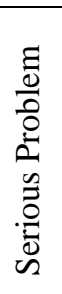 & & 离 & 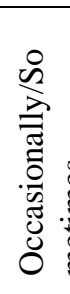 & 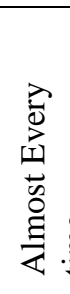 & 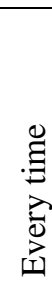 \\
\hline $\begin{array}{l}\text { 26. Being able to secure materials } \\
\text { due to lack of advanced pre- } \\
\text { planning of pre-service teacher(s) } \\
\text { was/occurred... }\end{array}$ & \begin{tabular}{l|}
1 \\
\end{tabular} & 2 & 3 & 4 & 5 & 1 & 2 & 3 & 4 & 5 \\
\hline $\begin{array}{l}\text { 27. Having a pre-service teacher(s) } \\
\text { who did not understand the time } \\
\text { commitment that comes with being } \\
\text { an agricultural instructor } \\
\text { was/occurred... }\end{array}$ & 1 & 2 & 3 & 4 & 5 & 1 & 2 & 3 & 4 & 5 \\
\hline $\begin{array}{l}\text { 28. The understanding of my pre- } \\
\text { service teacher(s) of the time } \\
\text { commitment needed to run the } \\
\text { total program was/occurred... }\end{array}$ & 1 & 2 & 3 & 4 & 5 & 1 & 2 & 3 & 4 & 5 \\
\hline
\end{tabular}

Please answer the following demographic questions by placing an " $X$ " on the line that best fits your answer.

29. What is your gender?

_ Male

_ Female

30. What category bests represents your age?

$25-29$
$-30-34$
$-35-39$
$-40-44$
$-44-49$
$-50+$


31. What is your highest obtained degree?

_ Bachelors

Masters

_ Doctorate

32. How many years of teaching experience do you have?

_ Less than 5

- 5-9

$-10-14$

$-15-19$

$-20+$

33. On average what is the total number of students in your program? (not FFA membership)

34. How many teachers are in your agricultural department?

$$
\begin{array}{r}
-1 \\
-2 \\
-3 \\
-4
\end{array}
$$

_ Other (please specify)

35. How many student teachers did you supervise from West Virginia University's Agricultural and Extension Education department between 2006-2016?

Thank you for your participation with my thesis research!

If you have any questions, please feel free to contact me:

Samantha Cogle

Email: scogle@mix.wvu.edu

Phone: (304) 641-5548 


\section{APPENDIX I}

Cover Letter - Phase III 
May 9, 2017

\section{Dear Cooperating Teacher:}

A few weeks ago we sent you Phase 2 of our study asking if you agree or disagree with identified challenges from Phase 1. I am happy to announce that we have analyzed the data and are now sending you the third and final phase of the survey. Phase 3 is comprised of the statements that $52 \%$ or more of the respondents from Phase 2 identified as challenges.

I am Samantha Cogle, a graduate student in Agricultural and Extension Education. Under the direction of my advisor, Dr. Stacy Gartin, we are conducting a study to determine the challenges that cooperating teachers encounter when supervising a student teacher. The results of this study will be used to prepare a thesis to partially fulfill the requirements of a Master of Science in Agricultural and Extension Education. We are contacting agricultural educators who have served as cooperating teachers for West Virginia University's agricultural education pre-service teachers between the years 2011 and 2016. The results will provide information to teacher educators in order to help better manage the student teacher experience.

Participation in this research study is completely voluntary and all information you provide will be held as confidential as possible. This study will be conducted in three phases with this being the second. This survey should only take about 8 minutes to complete. Your response is crucial to the success of the study. You may skip the question if you are not comfortable answering and you may stop at any time. Survey results will be reported in a summary format and individual responses will not be identifiable.

The Institutional Review Board (IRB) at West Virginia University has approved this study Protocol \#1702458725. If you have any questions or concerns about completing the questionnaire or about participating in this study, you may contact me at scogle@mix.wvu.edu or (304) 641-5548.

Please complete your survey before May 19, 2017. Thank you in advance for your assistance with this study, we sincerely appreciate your participation.

Respectfully yours,

Samantha L. Cogle

Graduate Student

Agricultural and Extension Education Education
Stacy A. Gartin, Ph.D.

Professor

Agricultural and Extension 
APPENDIX J

Follow-up Letter - Phase III 
May 22, 2017

Dear Cooperating Teacher:

A few weeks ago we sent you Phase 3 of our study to identify the challenges perceived by cooperating teachers while supervising a student teacher. Unless your response is in the mail we have not heard from you. This is the third and final phase of the survey and is comprised of the statements that $52 \%$ or more of the respondents from Phase 2 identified as challenges.

I am Samantha Cogle, a graduate student in Agricultural and Extension Education. Under the direction of my advisor, Dr. Stacy Gartin, we are conducting a study to determine the challenges that cooperating teachers encounter when supervising a student teacher. The results of this study will be used to prepare a thesis to partially fulfill the requirements of a Master of Science in Agricultural and Extension Education. We are contacting agricultural educators who have served as cooperating teachers for West Virginia University's agricultural education pre-service teachers between the years 2011 and 2016. The results will provide information to teacher educators in order to help better manage the student teacher experience.

Participation in this research study is completely voluntary and all information you provide will be held as confidential as possible. This study will be conducted in three phases with this being the third. This survey should only take about 8 minutes to complete. Your response is crucial to the success of the study. You may skip the question if you are not comfortable answering and you may stop at any time. Survey results will be reported in a summary format and individual responses will not be identifiable.

The Institutional Review Board (IRB) at West Virginia University has approved this study Protocol \#1702458725. If you have any questions or concerns about completing the questionnaire or about participating in this study, you may contact me at scogle@mix.wvu.edu or (304) 641-5548.

Please complete your survey before June 2, 2017. Thank you in advance for your assistance with this study, we sincerely appreciate your participation.

Respectfully yours,

Samantha L. Cogle

Graduate Student

Agricultural and Extension Education Education
Stacy A. Gartin, Ph.D.

Professor

Agricultural and Extension 
APPENDIX K

Second Follow-up Letter Phase III 
June 5, 2017

Dear Cooperating Teacher:

A few weeks ago we sent you Phase 3 of our study to identify the challenges perceived by cooperating teachers while supervising a student teacher. Unless your response is in the mail we have not heard from you. This is the third and final phase of the survey and is comprised of the statements that $52 \%$ or more of the respondents from Phase 2 identified as challenges.

I am Samantha Cogle, a graduate student in Agricultural and Extension Education. Under the direction of my advisor, Dr. Stacy Gartin, we are conducting a study to determine the challenges that cooperating teachers encounter when supervising a student teacher. The results of this study will be used to prepare a thesis to partially fulfill the requirements of a Master of Science in Agricultural and Extension Education. We are contacting agricultural educators who have served as cooperating teachers for West Virginia University's agricultural education pre-service teachers between the years 2011 and 2016. The results will provide information to teacher educators in order to help better manage the student teacher experience.

Participation in this research study is completely voluntary and all information you provide will be held as confidential as possible. This study will be conducted in three phases with this being the third. This survey should only take about 8 minutes to complete. Your response is crucial to the success of the study. You may skip the question if you are not comfortable answering and you may stop at any time. Survey results will be reported in a summary format and individual responses will not be identifiable.

The Institutional Review Board (IRB) at West Virginia University has approved this study Protocol \#1702458725. If you have any questions or concerns about completing the questionnaire or about participating in this study, you may contact me at scogle@mix.wvu.edu or (304) 641-5548.

Please complete your survey before June 16, 2017. Thank you in advance for your assistance with this study, we sincerely appreciate your participation.

Respectfully yours,

Samantha L. Cogle

Graduate Student

Agricultural and Extension Education

Education
Stacy A. Gartin, Ph.D.

Professor

Agricultural and Extension 
VITA 


\section{Samantha L. Cogle}

Email: scogle.12@gmail.com

Education: $\quad$ West Virginia University, Morgantown, WV 26506.

Pursuing a Master of Science in Agricultural and Extension

Education. Course work specializing in: Research methods, data analysis, forage crops, and educational psychology, foundations of learning.

Expected date of graduation August, 2017.

West Virginia University, Morgantown, WV 26506.

Earned a Bachelor of Science in Agriculture with a major in Agricultural and Extension Education. Course work specializing in: Teaching methods, shop theory methods, FFA/SAE, classroom management, agriculture extension, plant/soil science, agricultural mechanics, leadership, and communications.

Graduated August, 2015.

Potomac State College of West Virginia University, Keyser, WV 26726.

Earned an Associates of Arts in Agriculture with a major in Agricultural and Environmental Education.

Graduated May, 2013.

Certification: CASE Certified - Introduction to Agriculture, Food, and Natural Resources.

Professional

Experience:
Instructor, West Virginia University, Morgantown, WV.

Responsibilities included: Taught students in the AGEE 426

FFA/SAE course. Prepared the syllabus for the semester course, instructed students, and provided input and feedback to students about their assignments.

Accomplishments: Students improved vastly on their FFA and SAE knowledge.

Graduate Teaching Assistant, West Virginia University, Morgantown, WV.

Responsibilities included: Taught and assisted students in the AGEE 421 Agricultural Communications course. Led 8 other teaching assistants in grade and presentation discussions, provided students in the class with feedback on their assignments and graded them on oral presentations. Provided students with one-on-one instruction to prepare them for presentations. Assisted in selecting future teaching assistants for the course. 
Professional Experience: (continued)
Accomplishments: Students improved immensely in their communication skills. Students also improved by $80 \%$ when it came to giving presentations.

Student Teacher Intern, South Harrison High School, Lost Creek, WV.

Responsibilities included: Creating lesson plans, teaching students in different agricultural classes, and assisting with FFA activities. Accomplishments: Helped students improve their knowledge of agriculture.

Teaching Assistant, Agricultural and Natural Resources Communications (AGEE 421), West Virginia University, Morgantown, WV 26506.

Responsibilities included: Assisted in the planning, delivery, and evaluation of students' oral and written assignments. Provided leadership instruction for students during weekly recitation sessions. Collaborate in team-teaching lectures. Provided one-on-one instruction for students preparing for oral presentations. Accomplishments: Students in my group increased by 100\%, 75\% of the students in my group ended up being rated in the top $10 \%$ of the class. Two of the students in my group were selected to become teaching assistants for the course.

Mentor, Energy Express, Kearneysville, WV 25430.

Responsibilities included: Worked with elementary age children on reading, writing, drama, and art. Helped with several community service projects as well.

Accomplishments: Patience with students and teaching skills, on time to work daily, helped children increase their reading and writing skills.

Work Experience:

Child Care Provider, Cubby's Child Care Center, Bridgeport, WV.

Responsibilities included: Caring for children of different ages, helping with their meals, and assisting with educational activities.

Child Care Provider, Stacey Hough, Charles Town, WV 25414. Responsibilities include: Caring for children throughout the day.

Cashier, CVS Pharmacy, Charles Town, WV 25414.

Responsibilities included: Operated cash register, tended to customer needs, stocked shelves. 
Assistant Farm Manager, The BilMar, Charles Town, WV 25414. Responsibilities include: Nutrition of cattle, sheep, and swine, operating machinery, farm hand. Farm machinery maintenance including: refueling of equipment, changing of oil and filters, assessing minor issues (replacing bad fuel pumps, fuel lines, batteries).

Canine Care Provider, Barbara Rowan, Charles Town, WV 25414.

Responsibilities include: Nutrition of dogs, exercising dogs, and administering medicine.

Honors and West Virginia University, Morgantown, WV 26506.

Activities: Organizations:

- Gamma Sigma Delta

- Mountaineer Collegiate FFA- Graduate Student Advisor

- WVU Alpha Tau Alpha

Honors:

- President's List

- Dean's List

Potomac State College of West Virginia University, Keyser, WV 26726.

Organizations:

- Agriculture and Forestry Club- President

- Collegiate 4-H

Honors:

- Dean's List

Washington High School, Charles Town, WV 25414.

- Washington FFA Chapter

- President (2 years)

- Secretary (2 years)

- Prepared Public Speaking-State Winner

Personal Attributes: Responsible, Trustworthy, Dedicated, Honest. Information: Hobbies: Being outdoors, Reading, and Helping Others. 